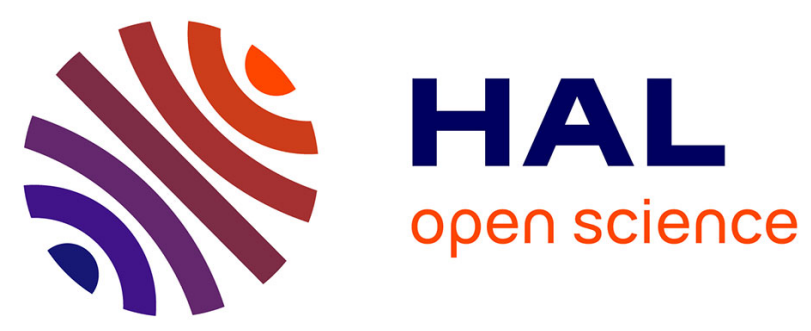

\title{
Construction of hydrogen bonding and coordination networks based on ethynylpyridine-appended nucleobases
}

Christophe Kahlfuss, Eliot Starck, Elsa Tufenkjian, Nathalie Kyritsakas, Abdelaziz Jouaiti, Stéphane Baudron, Mir Wais Hosseini, Véronique Bulach

\section{To cite this version:}

Christophe Kahlfuss, Eliot Starck, Elsa Tufenkjian, Nathalie Kyritsakas, Abdelaziz Jouaiti, et al.. Construction of hydrogen bonding and coordination networks based on ethynylpyridine-appended nucleobases. CrystEngComm, 2021, 23 (4), pp.944-954. 10.1039/D0CE01661F . hal-03322460

\section{HAL Id: hal-03322460 https://hal.science/hal-03322460}

Submitted on 19 Aug 2021

HAL is a multi-disciplinary open access archive for the deposit and dissemination of scientific research documents, whether they are published or not. The documents may come from teaching and research institutions in France or abroad, or from public or private research centers.
L'archive ouverte pluridisciplinaire HAL, est destinée au dépôt et à la diffusion de documents scientifiques de niveau recherche, publiés ou non, émanant des établissements d'enseignement et de recherche français ou étrangers, des laboratoires publics ou privés. 


\title{
Construction of hydrogen bonding and coordination networks based on ethynylpyridine-appended nucleobases
}

\author{
Christophe Kahlfuss, Eliot Starck, Elsa Tufenkjian, Nathalie Kyritsakas, Abdelaziz Jouaiti, \\ Stéphane A. Baudron, Mir Wais Hosseini and Véronique Bulach* \\ Université de Strasbourg, CNRS, CMC UMR 7140, 4 rue Blaise Pascal, F-67000, Strasbourg, France. Fax: \\ 33 368851325; Tel: 33 368851327; E-mail: bulach@unistra.fr
}

A series of eight derivatives bearing a 3- or 4-ethynylpyridine group and a nucleobase (adenine, cytosine, guanine or uracil) has been designed, synthesized and characterized. In particular, in the crystalline state, these derivatives form self-complementary hydrogen bonding motifs. Furthermore, the ability of these compounds to form complementary base pairs has been explored and two such hetero-molecular assemblies have been characterized in the solid state, using cytosine and guaninebased species. These pairs feature the expected hydrogen bonding recognition pattern, as observed in natural systems. Not only are these compounds prone to hydrogen bonding but they have been also employed as tectons for the formation of coordination networks upon association with a series of metal salts $\left(\mathrm{Cd}\left(\mathrm{NO}_{3}\right)_{2}, \mathrm{Cu}(\mathrm{OAc})_{2}\right.$ and $\mathrm{Cu}(\mathrm{hfac})_{2}$ ( $\mathrm{hfac}=$ hexafluoroacetylacetonate)). While, in some cases, both binding event can be observed with the pyridyl acting as a ligand and the nucleobase as an hydrogen bonding donor/acceptor, the tendency of the latter to also coordinate metal centers can lead to more complex assemblies. Thus, a similar 1D arrangement is observed resulting from coordination of the peripheral pyridyl group to the $\mathrm{Cu}(\mathrm{II})$ cations and self-complementary hydrogen bonding of either a uracil or cytosine moiety, upon assembly with $\mathrm{Cu}(\mathrm{hfac})_{2}$ or $\mathrm{Cu}(\mathrm{OAc})_{2}$ respectively. In these two cases, the nucleobases are not involved in coordination processes, unlike what is found in the other three networks obtained using the adenine-based tectons. In these networks, a recurrent self-complementary hydrogen bonding motif is found between the adenine moieties which also coordinate the metal cations via its N1 pyrimidinyl nitrogen atom. The dimensionality of these networks differs depending on the nature of the metal salt employed, the nuclearity of the metal node as well as the position of the pyridyl unit. These results demonstrate the soundness as well as the complexity associated with the combination of nucleobases with coordinating units for the construction of molecular networks.

\section{Introduction}

The construction of crystalline molecular networks has been the object of intense research over the past decades aiming at the elaboration of materials with designed properties and applications. The molecular tectonics approach represents an interesting and efficient strategy in this context, as it relies on the periodic association of building blocks, called tectons, bearing divergent (self-)complementary interaction sites. ${ }^{1}$ Among the many potential modes of association available in the crystal engineering toolbox, hydrogen bonding and coordination processes have been particularly investigated. For example, inspired from the ubiquity of hydrogen bonding interactions in biological systems, many synthetic assemblies have been developed using functionalized nucleobase (NB) derivatives, adenine $(A)$, cytosine (C), guanine (G), thymine (T) and uracil (U) (scheme 1). ${ }^{2,3}$ On the other hand, coordinationbased architectures have been also widely explored, especially with the advent of metal-organic frameworks and coordination polymers. ${ }^{4}$ In light of the appealing features of these two types of interactions, efforts have been made to combine them to build hybrid crystalline molecular architectures. ${ }^{5}$ For such purposes, derivatives comprising hydrogen bonding donor/acceptor groups as well as coordinating units are required. 
Interestingly, some functional groups can feature the ability to form both types of binding modes such as in the case of the above-mentioned nucleobases. Thus, these derivatives have been explored to afford a wide diversity of metal-organic assemblies. ${ }^{6}$ In an effort to take advantage of both binding processes, nucleobases appended with additional coordinating moieties have been reported and their assembly with metal cations has been investigated. ${ }^{7}$ Nucleobases functionalized by terpyridine, $2,2^{\prime}$ bipyridine or carboxylic acids have hence been described. Recently, our group has reported a series of nucleobases appended with a 4-pyridyl unit, ${ }^{8}$ with a methylene spacer providing flexibility. We were interested in investigating the impact of a more rigid spacer such as an ethynyl bridge. Hence, we report herein on a series of eight nucleobase derivatives bearing either a 3- or a 4-ethynylpyridine moiety, on their organization in the solid state by hydrogen bonding either as a stand-alone nucleobase or in cocrystals of base pairs and on their assembly with $\mathrm{Cd}\left(\mathrm{NO}_{3}\right)_{2}, \mathrm{Cu}(\mathrm{OAc})_{2}$ and $\mathrm{Cu}(\mathrm{hfac})_{2}$ (hfac $=$ hexafluoroacetylacetonate) towards the formation of coordination polymers.

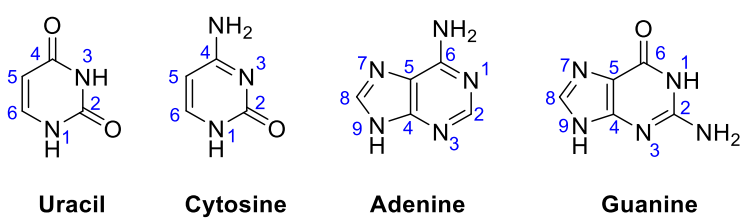

Scheme 1. Representation of the nucleobases employed in this study and numbering of the atoms in blue.

\section{Results and discussion}

\section{Synthesis and crystal structure of the free tectons}
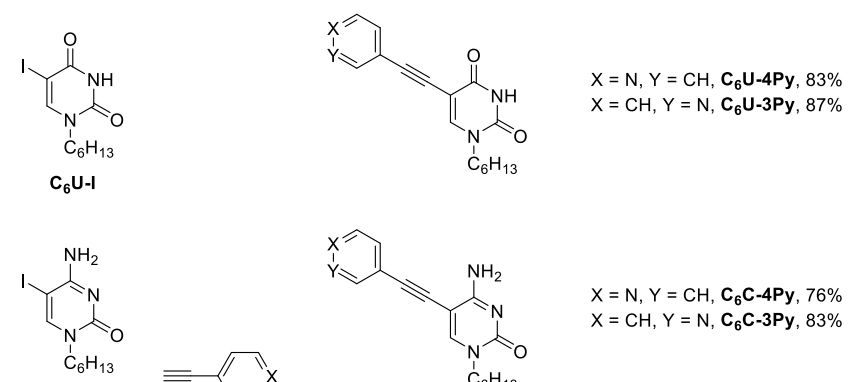

$\mathrm{C}_{6} \mathrm{C}-\mathrm{I}$
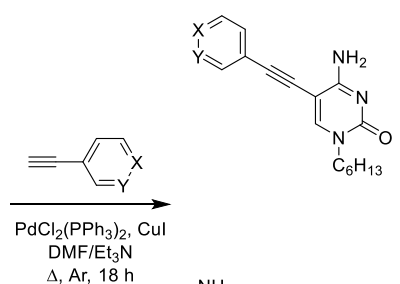

$\mathrm{X}=\mathrm{N}, \mathrm{Y}=\mathrm{CH}, \mathrm{C}_{6} \mathrm{C}-4 \mathrm{Py}, 76 \%$

$\mathrm{X}=\mathrm{CH}, \mathrm{Y}=\mathrm{N}, \mathrm{C}_{6} \mathrm{C}-3 \mathrm{Py}, 83 \%$

$$
\text { C-Br }
$$

$\mathrm{Ar}, 18 \mathrm{~h}$

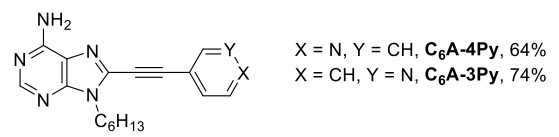<smiles>CCCCCCn1c(Br)nc2c(=O)[nH]c(N)nc21</smiles>

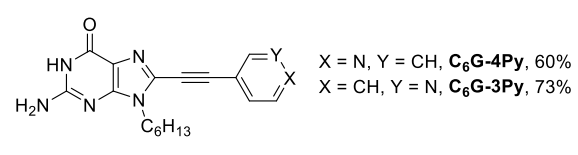

Scheme 2. Synthetic pathway for the preparation of the series of tectons $\mathbf{C}_{6}$ NB-3py and $\mathbf{C}_{6}$ NB-4py by Sonogashira coupling.

The tectons were designed to comprise a nucleobase unit bearing an ethynylpyridine group for coordination events as well as a $n$-hexyl chain to increase solubility. For the uracil and cytosine-based compounds, the alkyl chain was introduced at nitrogen $\mathrm{N} 1$ and the coordinating group at position 5 by Sonogashira coupling of the corresponding 1-hexyl-5-iodo $\mathbf{C}_{6} \mathbf{U}-\mathbf{I}$ or $\mathbf{C}_{6} \mathbf{C}-\mathbf{I}$ derivative ${ }^{9}$ with either 3- or 4- 
ethynylpyridine (Scheme 2). ${ }^{10}$ For the adenine and guanine species, coupling was performed using 8bromo-9-hexyladenine, $\mathbf{C}_{6} \mathbf{A}-\mathbf{B r},{ }^{11}$ and 8-bromo-9-hexylguanine, $\mathbf{C}_{6} \mathbf{G}-\mathbf{B r},{ }^{12}$ respectively (Scheme 1 ). Compounds were obtained with yields ranging from 60 to $87 \%$ and characterized in solution by ${ }^{1} \mathrm{H}-$ and ${ }^{13} \mathrm{C}$-NMR spectroscopy as well as by mass-spectrometry. Five of the eight new tectons were also characterized by single-crystal $\mathrm{X}$-ray diffraction (Table 1 ).

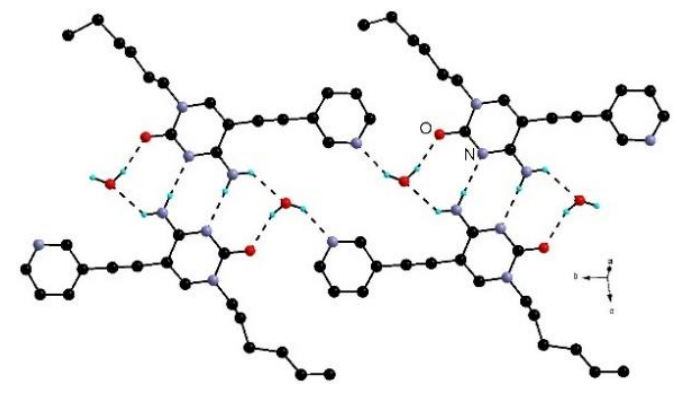

Fig. 1. A portion of the $1 \mathrm{D}$ - hydrogen bonding network in the crystal structure of $\mathrm{C}_{6} \mathrm{C}-3 \mathrm{Py} \mathrm{H}_{2} \mathrm{O}$. Only one position of the disordered hexyl chain is shown and the $\mathrm{C}-\mathrm{H}$ hydrogen atoms have been omitted for clarity.

Upon slow evaporation of the tecton in a $\mathrm{CHCl}_{3} / \mathrm{MeOH}$ solution, compound $\mathrm{C}_{6} \mathrm{C}-3 \mathrm{Py}$ crystallizes as a monohydrate in the triclinic $P$-1 space group with three crystallographically independent $\mathrm{C}_{6} \mathrm{C}-3 \mathrm{Py}-\mathrm{H}_{2} \mathrm{O}$ pairs (Fig. 1). The molecule is rather flat as the pyridyl ring and the cytosine moiety form an angle ranging from 2.2 to $12.9^{\circ}$. Hydrogen bonding between the cytosine moieties involve amine and the N3 pyrimidyl nitrogen atom in a complementary fashion $\left(\mathrm{d}_{\mathrm{N}-\mathrm{N}}=2.961(3)-2.984(3) \AA \AA\right.$ ). This type of dimeric organization has been reported for other functionalized cytosine derivatives. ${ }^{13}$ The carbonyl oxygen atoms is hydrogen bonded to a water molecule ( $\mathrm{d}_{\mathrm{o}-\mathrm{o}}=2.834(3)-2.850(3) \AA$ ). Interestingly, the peripheral 3-pyridyl group acts as an acceptor and interacts with water molecules as well $\left(\mathrm{d}_{\mathrm{N}(\mathrm{Pyr})-\mathrm{O}}=\right.$ 2.869(3)-2.916(3) A). This leads to the formation of a 1D network along the $b$ axis (Fig. 1) These 1D assemblies are stacked in the crystal via van der Waals interactions involving the hexyl chains thus forming 2D arrangements in the $b c$ plane. These planes are stacked along the $a$ axis.

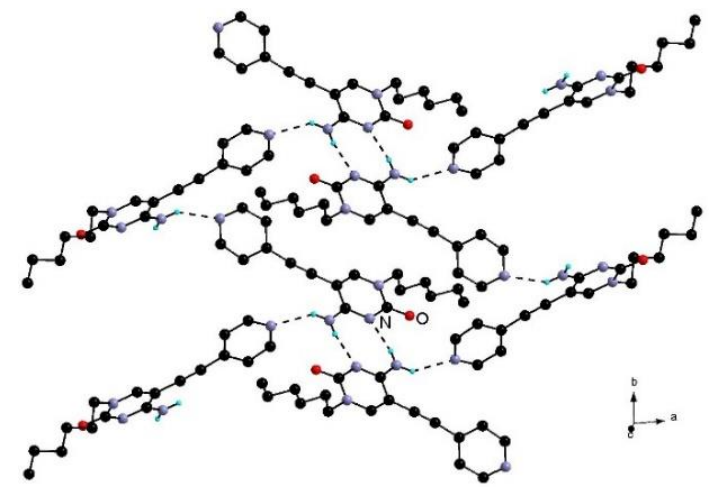

Fig. 2. A portion of the $2 \mathrm{D}$ hydrogen bonding network in the crystal structure of $\mathrm{C}_{6} \mathrm{C}-4 \mathrm{Py}$. Only the $\mathrm{NH}$ hydrogen atoms are presented for clarity.

Liquid diffusion of $\mathrm{Et}_{2} \mathrm{O}$ in a 1,2-dichloroethane (1,2-DCE) solution of $\mathbf{C}_{6} \mathrm{C}-4 \mathrm{Py}$ afforded crystals suitable for structure determination by $X$-ray diffraction (monoclinic $P 2_{1} / c$ ). Unlike the 3-pyridyl analogue, this compound crystallizes alone without the presence of solvent molecules and the torsion angle between the pyridyl ring and the cytosine ring is $26.1^{\circ}$. Interestingly, the cytosine moieties are hydrogen bonded at the amine and pyrimidyl units $\left(\mathrm{d}_{\mathrm{N}-\mathrm{N}}=3.028(2) \AA\right)$ forming centrosymmetric pairs, as observed for the $\mathrm{C}_{6} \mathrm{C}-3 \mathrm{Py}$ compound. The remaining $\mathrm{N}-\mathrm{H}$ interacts with the peripheral pyridyl nitrogen atom of a 
neighbouring molecule $\left(\mathrm{d}_{\mathrm{N}-\mathrm{N}}=3.032(2) \AA\right)$. This pattern leads to a $2 \mathrm{D}$ arrangement in the crystalline state (Fig. 2). It is worth noting that here the carbonyl oxygen atom is not involved in the formation of the hydrogen bonding network.

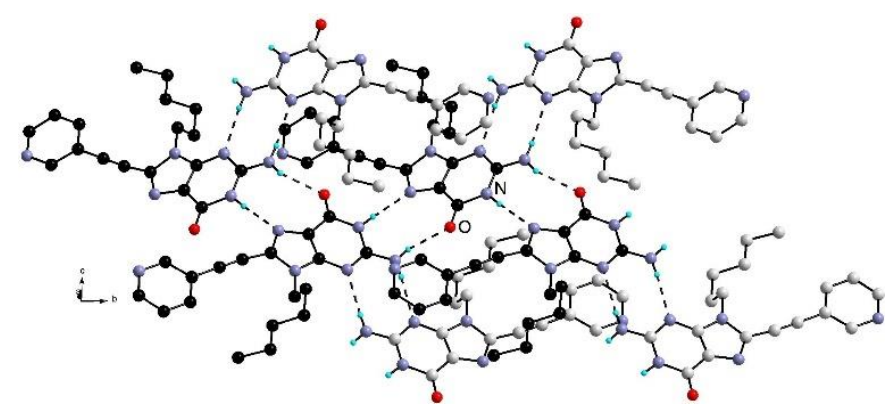

Fig. 3. A portion of the $1 \mathrm{D}$ ribbon in the crystal structure of $\mathbf{C}_{6} \mathbf{G}-3 P y$. Note that the carbon atoms of the molecules above and below the 1D chain have been coloured in light grey for clarity. The $\mathrm{CH}$ hydrogen atoms have been omitted to simplify the presentation.

Upon vapour diffusion of $\mathrm{MeOH}$ into a $\mathrm{CHCl}_{3}$ solution of $\mathrm{C}_{6} \mathbf{G}-3 \mathrm{Py}$, crystals (monoclinic, $P 2_{1} / c$ ) were obtained. In this compound, the guanine moiety and the pyridyl ring are almost coplanar as they form an angle of $1.7^{\circ}$. It can be noted that the nitrogen atom of the 3-pyridyl shows positional disorder and is thus distributed over two sites, most likely as a result of its absence of involvement in hydrogen bonding. The guanine units assemble into a ribbon-like organization triggered by the formation of intermolecular hydrogen bonds involving all donor and acceptor groups of the nucleobase $\left(\mathrm{d}_{\mathrm{N}-\mathrm{N}}=\right.$ 3.042(1) $\AA$ and $\mathrm{d}_{\mathrm{N}-\mathrm{O}}=2.888(1) \AA$ ) (Fig. 3). Interestingly, the arrangement observed is similar to what has been reported for an analogous derivative comprising a 4-ethynylpyridine instead of 3 ethynylpyridine and with a different substitution on the N9 position of the guanine moiety. ${ }^{14}$

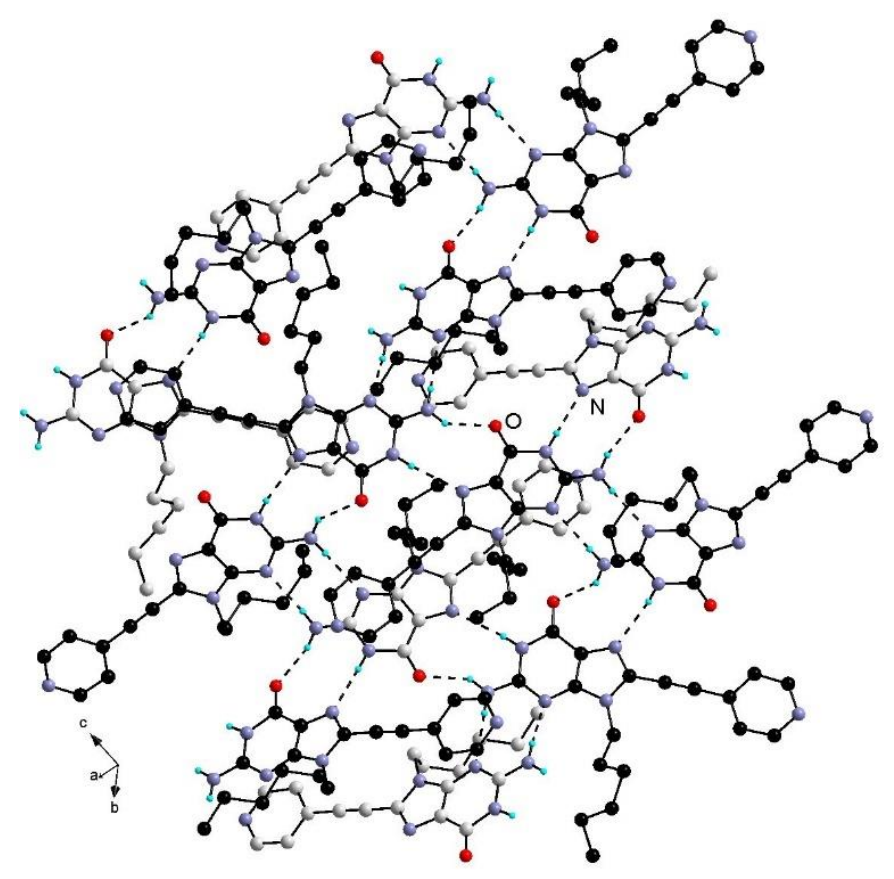

Fig. 4. Hydrogen bonding network in the crystal structure of $\mathbf{C}_{6} \mathbf{G}-\mathbf{4 P y}$. For clarity, the $\mathrm{CH}$ hydrogen atoms have been omitted and some carbon atoms are presented in light grey. 
Monocrystals of $\mathbf{C}_{6} \mathrm{G}-4 \mathrm{Py}$ were obtained by liquid diffusion of $\mathrm{Et}_{2} \mathrm{O}$ in a 1,2-DCE solution of the compound. This tecton crystallizes in the triclinic $P-1$ space group with four crystallographically independent molecules in the asymmetric unit featuring almost coplanar guanine and pyridyl units as angles between these moieties range from 1.1 to $9.1^{\circ}$. The hydrogen bonding network is complex as each independent $\mathbf{C}_{6} \mathbf{G}-\mathbf{4 P y}$ is involved in a different set of interactions between guanine moieties of either two or three neighbours ( $\mathrm{d}_{\mathrm{N}-\mathrm{N}} \approx 3.0 \AA$ and $\mathrm{d}_{\mathrm{N}-\mathrm{O}} \approx 2.8 \AA$ ). On the other hand, the pyridyl groups are found to not act as hydrogen bonding acceptors in this structure.

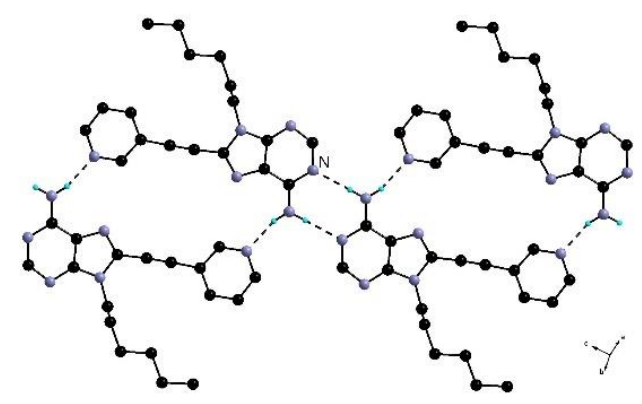

Fig. 5. A portion of the $1 \mathrm{D}$ hydrogen bonding network in the crystal structure of $\mathbf{C}_{6} \mathbf{A}-3 \mathbf{P y}(1,2-\mathrm{DCE})$. $\mathrm{CH}$ hydrogen atoms and solvent molecules have been omitted for clarity.

Slow evaporation of a 1,2-DCE/MeOH solution of $\mathbf{C}_{6} \mathrm{~A}-3 \mathrm{PPy}$ afforded crystals of the 1,2-DCE solvate (triclinic, $P$-1). The adenine moiety and the 3-pyridyl group form an angle of $10.1^{\circ}$ and are both involved in the formation of a 1D hydrogen bonding network. One amine $\mathrm{N}-\mathrm{H}$ is interacting with the $\mathrm{N} 1$ pyrimidyl nitrogen atom of the nucleobase $\left(d_{N-N}=3.011(4) \AA\right)$, whereas the remaining $\mathrm{N}-\mathrm{H}$ is hydrogen bonded to the pyridyl unit of another neighbouring molecule $\left(d_{N-N}=2.992(5) \AA\right)$ (Fig. 5).

\section{Tecton base pairs}

With these eight tectons in hand, it appeared of interest to assess their ability to form co-crystals based on complementary base pairing. Two such tectons base pairs were obtained using the novel derivatives described herein (Table 2).

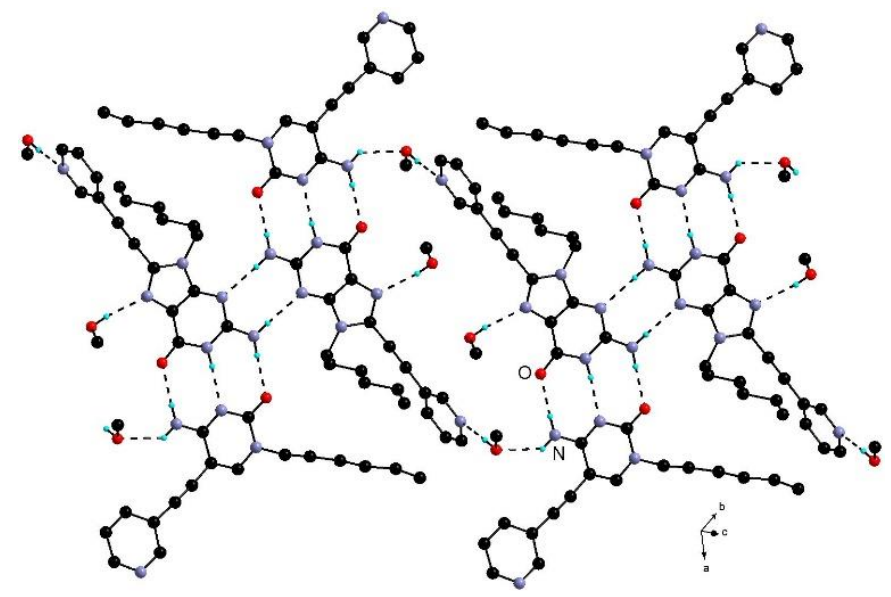

Fig. 6. A portion of the $1 \mathrm{D}$ hydrogen bonded network in the structure of $\mathbf{C}_{6} \mathbf{G}-3 P y \cdot \mathbf{C}_{6} \mathbf{C}-3 P y(\mathrm{MeOH})_{2}$. $\mathrm{CH}$ hydrogen atoms have been omitted for clarity.

Slow evaporation of a 1:1 mixture of $\mathbf{C}_{6} \mathbf{G}-3 \mathbf{P y}$ and $\mathbf{C}_{6} \mathrm{C}-3 \mathbf{P y}$ in $\mathrm{CH}_{2} \mathrm{Cl}_{2} / \mathrm{MeOH}$ afforded crystals of $\mathbf{C}_{6} \mathbf{G}$ $3 \mathbf{P y} \cdot \mathrm{C}_{6} \mathbf{C}-3 \mathbf{P y}(\mathrm{MeOH})_{2}$. This methanol solvate incorporating both complementary nucleobases and two molecules of solvent crystallized in the triclinic $P-1$ space group (Fig. 6 ). Whereas, for $\mathbf{C}_{6} \mathbf{C}-3 \mathbf{P y}$, the cytosine derivative remains coplanar with the 3-pyridyl group $\left(9.0^{\circ}\right)$ as observed in the structure of the 
free ligand, the guanine and pyridyl moiety are almost perpendicular in $\mathbf{C}_{6} \mathbf{G}-3 \mathbf{P y}\left(84.5^{\circ}\right)$ unlike for the free tecton. In addition to this deviation, the main feature of this structure is the formation of a Watson-Crick type complementary pair by interaction of the cytosine and guanine moieties via three hydrogen bonds $\left(\mathrm{d}_{\mathrm{N}-\mathrm{N}}=2.905(2) \AA\right.$ and $\left.\mathrm{d}_{\mathrm{N}-\mathrm{O}}=2.832(2)-2.850(2) \AA\right)$. This is analogous to other model base pairs reported in the literature. ${ }^{15}$ Here, these pairs are hydrogen bonded by additional interactions between neighbouring guanine units $\left(d_{N-N}=3.018(2) \AA\right)$, thus forming tetramers. These tetrameric arrangements are further connected by hydrogen bonds with $\mathrm{MeOH}$ molecules acting as an acceptor with a cytosine amine $\mathrm{NH}\left(\mathrm{d}_{\mathrm{N}-\mathrm{O}}=2.894(2) \AA\right)$ and as donors towards the pyridyl group ( $\mathrm{d}_{\mathrm{O}-\mathrm{N}}=$ $2.814(3) \AA ̊()$ and N7 nitrogen atom $\left(\mathrm{d}_{\mathrm{O}-\mathrm{N}}=2.887(2) \AA\right.$ ) of the guanine moiety of the $\mathrm{C}_{6} \mathrm{G}-3$ Py derivative.

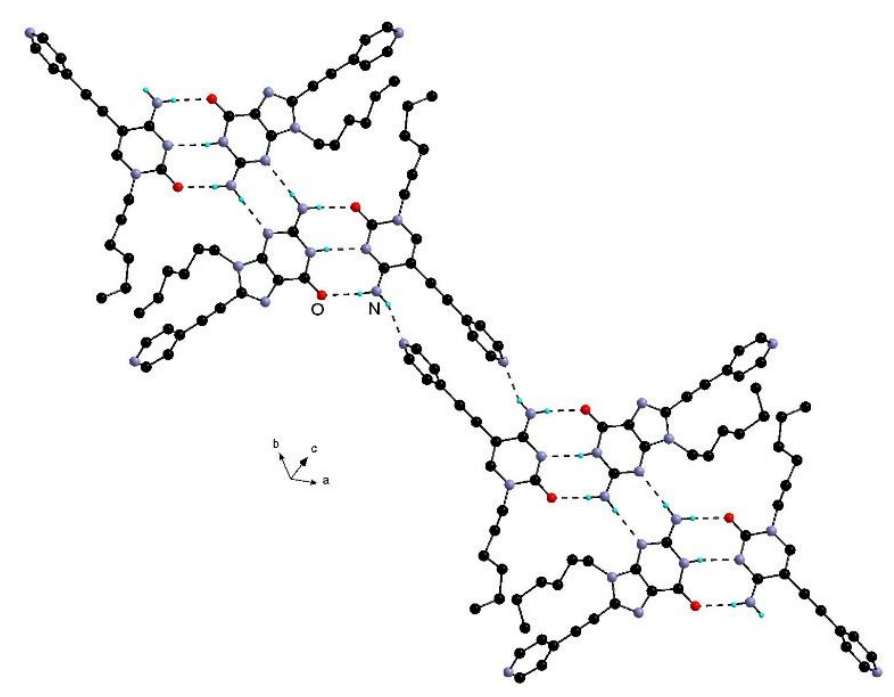

Fig. 7. A portion of the $1 \mathrm{D}$ hydrogen bonding network in $\mathbf{C}_{6} \mathbf{G}-4 \mathbf{P y} \cdot \mathbf{C}_{6} \mathbf{C}-4 \mathrm{Py}$ cocrystal. $\mathrm{CH}$ hydrogen atoms have been omitted for clarity. Only one position of the disordered hexyl chains is shown.

An analogous base pair based on the 4-pyridyl appended derivatives was obtained by vapour diffusion

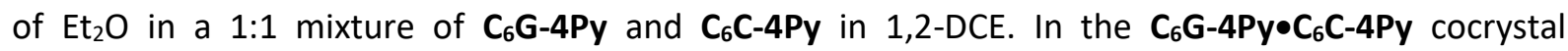
(monoclinic, $P 2_{1} / c$ ), a strong deviation from coplanarity is observed between the nucleobases and the pyridyl units, at variance with the structures of the free tectons. In $\mathbf{C}_{6} \mathbf{G}-\mathbf{4 P y}$, an angle of $65.6^{\circ}$ is observed between the two units, while the cytosine and the coordinating group form an angle of $82.9^{\circ}$ in $\mathbf{C}_{6} \mathbf{C}-4 \mathrm{Py}$. As for the 3-pyridyl analogue, Watson-Crick hydrogen bonded pairs are observed between the cytosine and guanine moieties $\left(\mathrm{d}_{\mathrm{N}-\mathrm{N}}=2.953(2) \AA, \mathrm{d}_{\mathrm{N}-\mathrm{O}}=2.875(2)-2.883(2) \AA\right.$ ) (Fig. 7). Here again, the interaction between neighbouring guanine groups $\left(d_{N-N}=3.107(2) \AA\right)$ affords tetrameric assemblies. Hydrogen bonding between the remaining amine $\mathrm{NH}$ and the peripheral pyridyl unit of the $\mathrm{C}_{6} \mathrm{C}-4$ Py derivative $\left(\mathrm{d}_{\mathrm{N}-\mathrm{N}}=3.024(3) \AA\right)$ leads to the formation of a 1D network of tetramers (Fig. 7).

\section{Combining coordination and hydrogen bonding}

These eight new tectons not only can assemble by hydrogen bonding, as demonstrated above, but are also prone to coordination through the peripheral ethynylpyridyl unit as well as through the nucleobase moiety itself. Thus, these derivatives were investigated for their ability to form coordination polymers, upon association with a variety of metal salts. Crystalline material could so far be obtained with $\mathrm{Cd}\left(\mathrm{NO}_{3}\right)_{2}, \mathrm{Cu}(\mathrm{OAC})_{2}$ and $\mathrm{Cu}(\mathrm{hfac})_{2}$ (Table 3).

Upon slow evaporation of a 1,2-DCE/MeOH solution of $\mathbf{C}_{6} \mathrm{U}-4 \mathrm{Py}$ and $\mathrm{Cu}(\mathrm{hfac})_{2}(0.5 \mathrm{eq})$, crystals of $\left[\left(\mathrm{C}_{6} \mathrm{U}-4 \mathrm{Py}\right)_{2} \mathrm{Cu}(\mathrm{hfac})_{2}\right] .(1,2-\mathrm{DCE})_{2}$ were obtained and characterized by $\mathrm{X}$-ray diffraction (Triclinic, $P-1$ ) (Fig. 8a). In this compound, the $\mathrm{Cu}$ (II) cation is an octahedral coordination environment, bound to the two capping hfac anionic ligands in the square base and to the pyridyl groups of two $\mathbf{C}_{6} \mathrm{U}-4 \mathrm{Py}$ tectons 
$\left(d_{\mathrm{Cu}-\mathrm{N}}=2.0422(15) \AA\right)$. The uracil moiety forms an angle of $49.8^{\circ}$ with the pyridyl unit and is not involved in coordination processes. It rather forms a self-complementary hydrogen bonding motif with a neighbouring nucleobase $\left(\mathrm{d}_{\mathrm{N}-\mathrm{O}}=2.815(3) \AA ̊\right)$ leading to an overall $1 \mathrm{D}$ arrangement (Fig. 8a).

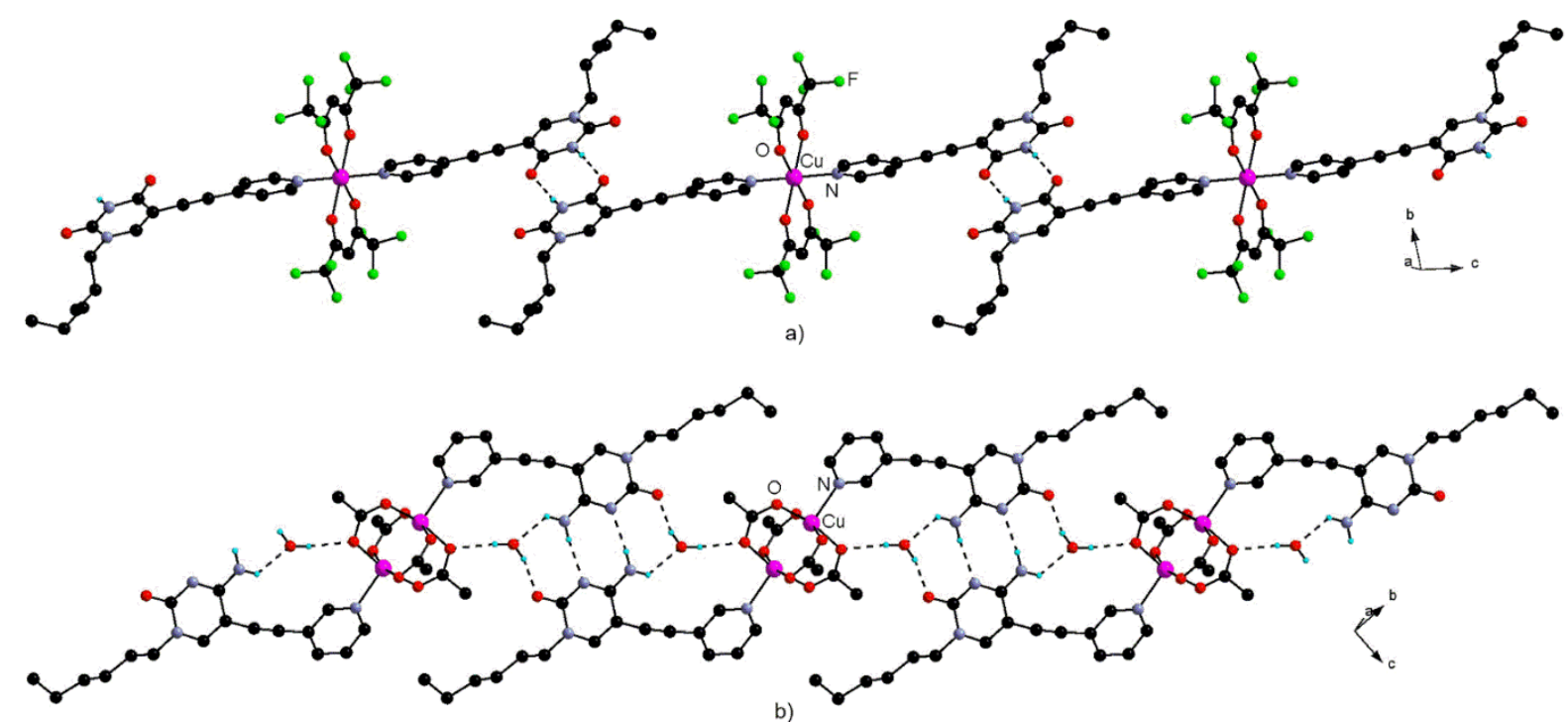

Fig. 8. A portion of the $1 \mathrm{D}$ networks formed by a self-assembly by hydrogen bonding of metalnucleobase assemblies $\left[\left(\mathrm{C}_{6} \mathrm{U}-4 \mathrm{Py}\right)_{2} \mathrm{Cu}(\mathrm{hfac})_{2}\right] .(1,2-\mathrm{DCE})_{2}$ (a) and $\left[\left(\mathrm{C}_{6} \mathrm{C}-3 \mathrm{Py}\right)_{2}\left(\mathrm{Cu}(\mathrm{OAC})_{2}\right)_{2}\right]\left(\mathrm{H}_{2} \mathrm{O}\right)_{2}$ (b). C-H hydrogen atoms have been omitted for clarity.

Interestingly an analogous organization is observed in $\left[\left(\mathrm{C}_{6} \mathrm{C}-3 \mathrm{Py}\right)_{2}\left(\mathrm{Cu}(\mathrm{OAC})_{2}\right)_{2}\right]\left(\mathrm{H}_{2} \mathrm{O}\right)_{2}$ (Triclinic, $\mathrm{P}-1$ ) obtained by slow evaporation of a solution containing $\mathrm{C}_{6} \mathrm{C}-3 \mathrm{Py}$ and $\mathrm{Cu}(\mathrm{OAC})_{2}(1 \mathrm{eq})$ in $1,2-\mathrm{DCE} / \mathrm{CH}_{3} \mathrm{CN}$. Here, two $\mathrm{Cu}(\mathrm{II})$ cations form the prototypical paddlewheel motif with four acetate anions, while the pyridyl group of two tectons occupy the remaining axial positions ( $d_{C u-N}=2.192(1) \AA$ ). The nucleobase forms an angle with the peripheral coordinating unit of $25.7^{\circ}$, larger than in the structures of the free ligand and of the $\mathbf{C}_{6} \mathbf{G}-3 \mathbf{P y} \cdot \mathbf{C}_{6} \mathbf{C}-\mathbf{3 P y}(\mathrm{MeOH})_{2}$ base pair. Interestingly, the cytosine forms the same complementary hydrogen bonding pattern as seen in $\mathrm{C}_{6} \mathrm{C}-3 \mathrm{Py} \cdot \mathrm{H}_{2} \mathrm{O}$ (Fig. 1), involving two nucleobases and two water molecules. The amino $\mathrm{N}-\mathrm{H}$ is interacting with the $\mathrm{N} 1$ pyrimidine nitrogen atom $\left(\mathrm{d}_{\mathrm{N}-\mathrm{N}}=\right.$ 2.944(2) $\AA$ ), while the water molecule acts as a donor towards the carbonyl group ( $\mathrm{d}_{\mathrm{o}-\mathrm{o}}=2.806(2) \AA$ ) and as an acceptor with respect to the second amine $\mathrm{N}-\mathrm{H}\left(\mathrm{d}_{\mathrm{N}-\mathrm{O}}=2.881(2) \AA\right)$. It should be noted that the water molecule is further hydrogen bonded to an acetate ligand of the paddlewheel motif $\left(\mathrm{d}_{\mathrm{o}-\mathrm{o}}=\right.$ 2.955(2) $\AA$ ). While the motifs are different between the two structures, the overall organization into 1D networks by combination of coordination by the peripheral pyridyl unit and complementary hydrogen bonding by the nucleobase moiety is similar. Whereas, in these two compounds, neither the uracil nor the cytosine group acts as a ligand towards the metal cation, the situation is at variance in the following examples.

Slow evaporation of a 1,2-DCE/MeOH solution of $\mathrm{C}_{6} \mathrm{~A}-3 \mathrm{Py}$ and $\mathrm{Cu}(\mathrm{hfac})_{2}(0.5 \mathrm{eq})$ afforded crystals of $\left[\left(\mathrm{C}_{6} \mathrm{~A}-3 \mathrm{Py}\right) \mathrm{Cu}(\mathrm{hfac})_{2}\right]\left(\mathrm{H}_{2} \mathrm{O}\right)$ (Triclinic, P-1) (Fig. 9). The coordination environment of the two crystallographically independent $\mathrm{Cu}(\mathrm{II})$ cations is octahedral with two capping hfac ligands forming a square base. The apical positions are occupied either by two pyridyl groups of two tectons $\left(\mathrm{d}_{\mathrm{Cu}-\mathrm{N}}=\right.$ $2.026(4) \AA$ ) or by the N1 nitrogen atom of two adenine moieties ( $d_{C u-N}=2.117(3) \AA$ ). This leads to a $1 D$ coordination network showing an undulation resulting from the alternation of the two $\mathrm{Cu}$ (II) cations with different coordination sphere and the $56.7^{\circ}$ angle between the pyridyl group and the adenine unit (Fig. 9a). The 1D coordination polymers are connected via Hoogsteen-type hydrogen bonding between the amine $\mathrm{NH}$ and the N7 nitrogen atom $\left(\mathrm{d}_{\mathrm{N}-\mathrm{N}}=3.012(5) \AA\right)$ of nucleobases of neighbouring 
assemblies. ${ }^{16}$ It can be noted that, although the motif is similar to what has been observed in the structure of the free ligand $\mathbf{C}_{6} \mathbf{A}-\mathbf{3 P y}$, another nitrogen atom acts here as a hydrogen bonding acceptor. Furthermore, the remaining amine $\mathrm{N}-\mathrm{H}$ is interacting with one oxygen atom of a hfac ligand $\left(\mathrm{d}_{\mathrm{N}-\mathrm{O}}=\right.$ $2.948(5) \AA ̊)$. The combination of coordination and hydrogen bonding patterns yields an overall 2D arrangement (Fig. 9b).

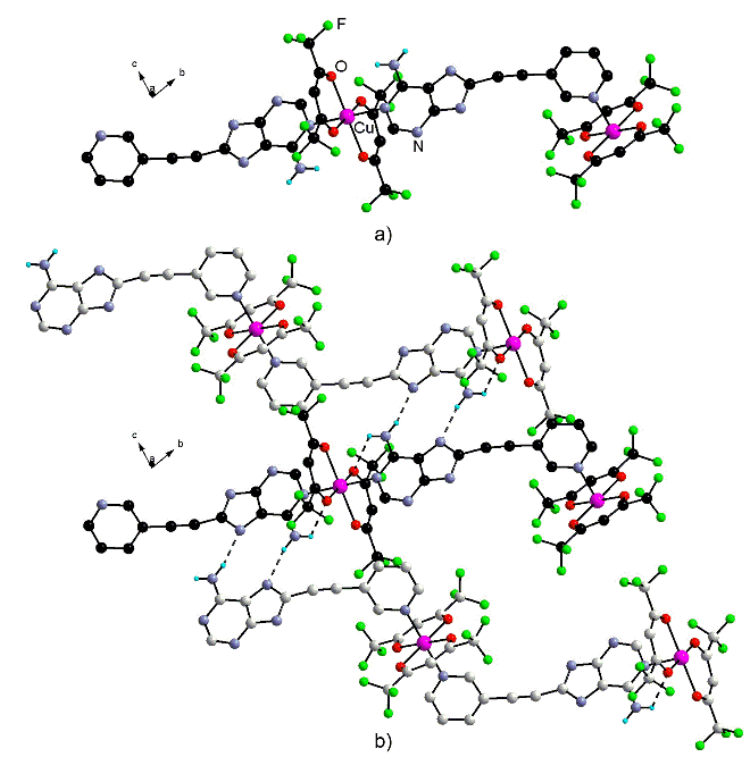

Fig. 9. A portion of the $1 \mathrm{D}$ coordination network in $\left[\left(\mathrm{C}_{6} \mathrm{~A}-3 \mathrm{Py}\right) \mathrm{Cu}(\mathrm{hfac})_{2}\right]\left(\mathrm{H}_{2} \mathrm{O}\right)(\mathrm{a})$ and hydrogen bonding between these 1D chains (b). The $n$-hexyl chains and $\mathrm{C}-\mathrm{H}$ hydrogen atoms have been omitted for clarity.

The same tecton afforded another network upon combination with $\mathrm{Cd}\left(\mathrm{NO}_{3}\right)_{2}$. Slow evaporation of a 1,2-DCE/MeOH/CH $3{ }_{3} \mathrm{CN}$ solution of $\mathrm{C}_{6} \mathrm{~A}-3 \mathrm{Py}$ and $\mathrm{Cd}\left(\mathrm{NO}_{3}\right)_{2}\left(\mathrm{H}_{2} \mathrm{O}\right)_{4}$ (1/2 ratio) led to the formation of crystals of $\left[\left(\mathbf{C}_{6} \mathrm{~A}-3 \mathrm{Py}\right)_{2} \mathrm{Cd}\left(\mathrm{NO}_{3}\right)_{2}\right](1,2-\mathrm{DCE})_{0.5}(\mathrm{MeOH})$ (monoclinic, $\left.\mathrm{P} 2 / n\right)$ (Fig. 10). Note that the same material is obtained upon combining the tecton and metal salt in a $1 / 1$ ratio. In this network, the $\mathrm{Cd}(\mathrm{II})$ cation is in an octahedral environment with two nitrate anions in the axial positions, two pyridyl groups in trans positions $\left(\mathrm{d}_{\mathrm{Cu}-\mathrm{N}}=2.330(6)\right.$ and $2.346(7) \AA$ ) and the $\mathrm{N} 1$ adenine nitrogen atoms of two nucleobases also in a trans arrangement $\left(\mathrm{d}_{\mathrm{Cu}-\mathrm{N}}=2.394(3)\right.$ and $\left.2.416(5) \AA\right)$. The two independent tectons showing a distortion between the pyridyl and nucleobase moieties $\left(79.4\right.$ and $\left.82.5^{\circ}\right)$ thus act as bridging units between the $\mathrm{Cd}(\mathrm{II})$ cations distant of around $14.2 \AA$, leading to an overall $2 \mathrm{D}$ coordination network (Fig. 10b). Interestingly, the cavities of the network are occupied by another 2D assembly leading to a two-fold interpenetration that is supported by the same hydrogen bonding motif between adenine groups $\left(\mathrm{d}_{\mathrm{N}-\mathrm{N}}=3.036(8)-3.071(7) \AA\right.$ ) (Fig. 10c) as in $\left[\left(\mathrm{C}_{6} \mathrm{~A}-3 \mathrm{Py}\right) \mathrm{Cu}(\mathrm{hfac})_{2}\right]\left(\mathrm{H}_{2} \mathrm{O}\right)$. The interpenetrated network form 2D sheets that are separated along the $c$ axis by 1,2-DCE and MeOH molecules as well as pendant $n$-hexyl chains. 


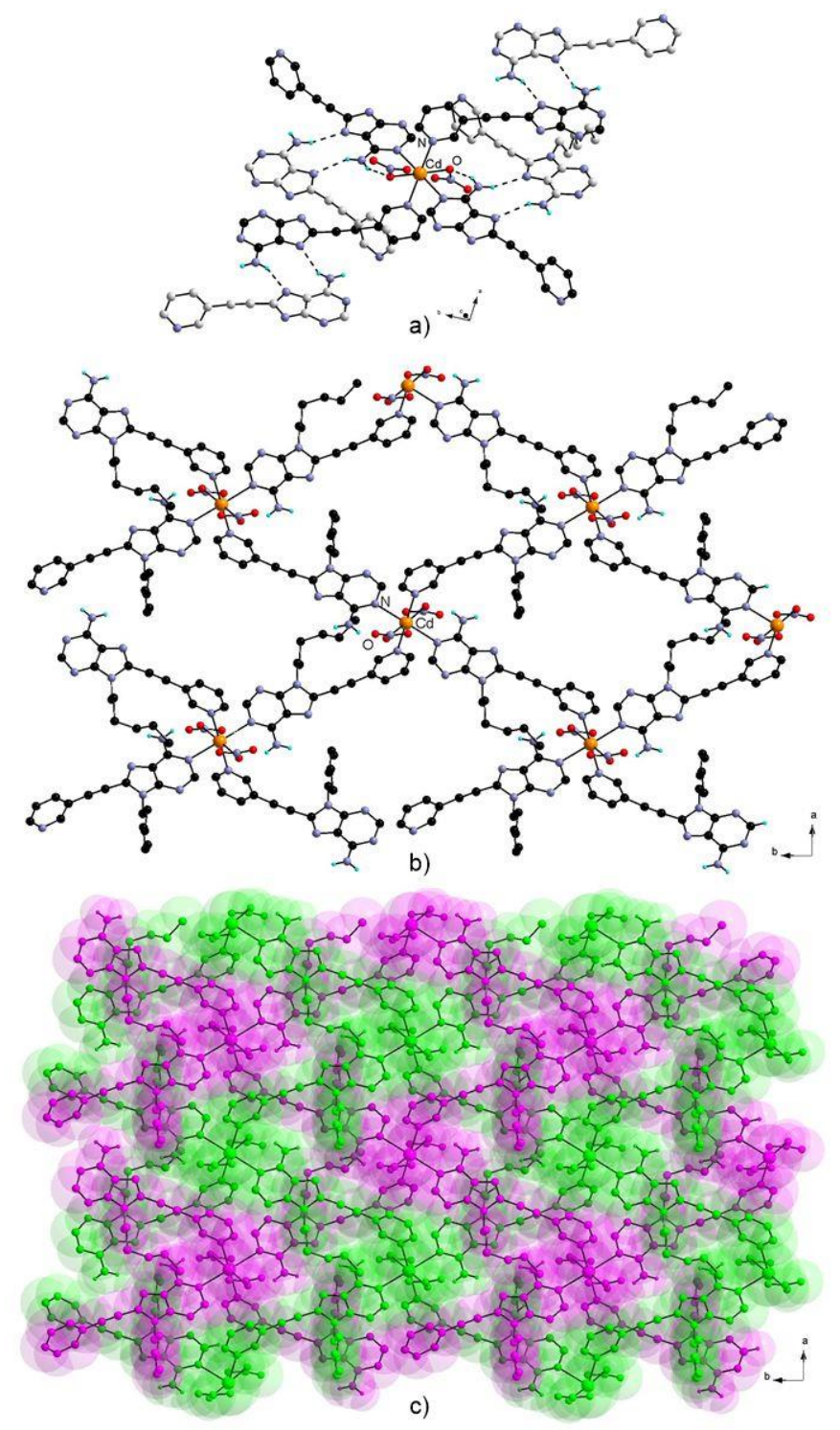

Fig. 10. Three views of the crystal structure of $\left[\left(\mathrm{C}_{6} \mathrm{~A}-3 \mathrm{Py}\right)_{2} \mathrm{Cd}\left(\mathrm{NO}_{3}\right)_{2}\right](1,2-\mathrm{DCE})_{0.5}(\mathrm{MeOH})$. Coordination sphere of the $\mathrm{Cd}(\mathrm{II})$ cation and hydrogen bonding of the bound tecton (the $n$-hexyl chains have been omitted for clarity) (a), a portion of the 2D network (b) and representation of the interpenetration (c). For more readability, the $\mathrm{C}-\mathrm{H}$ hydrogen atoms are not shown and only a position of the disordered $n$ hexyl chains is presented.

Starting from the 4-pyridyl analogue $\mathrm{C}_{6} \mathrm{~A}-4 \mathrm{Py}$, the combination with $\mathrm{Cd}\left(\mathrm{NO}_{3}\right)_{2}$ afforded a different network. Indeed, slow evaporation of a 1,2-DCE/MeOH/CH $\mathrm{CH}_{3} \mathrm{CN}$ solution of $\mathbf{C}_{6} \mathrm{~A}-4 \mathrm{Py}$ and $\mathrm{Cd}\left(\mathrm{NO}_{3}\right)_{2}\left(\mathrm{H}_{2} \mathrm{O}\right)_{4}$ (1 eq.) yielded crystals of $\left[\left(\mathrm{C}_{6} \mathrm{~A}-4 \mathrm{Py}\right)\left(\mathrm{Cd}\left(\mathrm{NO}_{3}\right)_{2}\left(\mathrm{H}_{2} \mathrm{O}\right)\right)\right](1,2-\mathrm{DCE})$ characterized by X-ray diffraction (triclinic, $P$-1) (Fig. 11). In this compound, the tecton is less twisted, as the 4-pyridyl unit and adenine moiety form an angle of $16.7^{\circ}$. Another difference lies in the presence of a binuclear node comprising two $C d(I I)$ cations ( $d_{C d-C d}=4.482(4) \AA$ ) bridged by nitrate anions. Their coordination sphere is completed each by another nitrate anion and a water molecule, while a pyridyl group and the N1 nitrogen atom of the adenine moiety of two tectons occupy the axial positions $\left(d_{C d-N}=2.276(2)\right.$ and 2.294 (2) $\AA$, respectively). This leads to the formation of a $1 \mathrm{D}$ network of binuclear nodes bridged by parallel $\mathbf{C}_{6} \mathbf{A}-$ 4Py tectons. In addition to coordination, the assembly also features hydrogen bonding. Within the binuclear node, the water molecules are interacting with nitrate anions ( $d_{0-0}=2.751(3) \AA$ ) Another nitrate oxygen atom acts as an acceptor for an amine $\mathrm{N}-\mathrm{H}$ of the adenine group $\left(\mathrm{d}_{\mathrm{N}-\mathrm{O}}=2.938(2) \AA\right)$. 
Most importantly, as for the networks obtained with $\mathbf{C}_{6}-\mathbf{A}-\mathbf{3 P y}$, a self-complementary motif is observed between adenine groups of neighbouring 1D chains, involving the amine $\mathrm{N}-\mathrm{H}$ and the $\mathrm{N} 7$ nitrogen atom. $\left(\mathrm{d}_{\mathrm{N}-\mathrm{N}}=3.088(2) \AA\right.$ ) (Fig. 11).

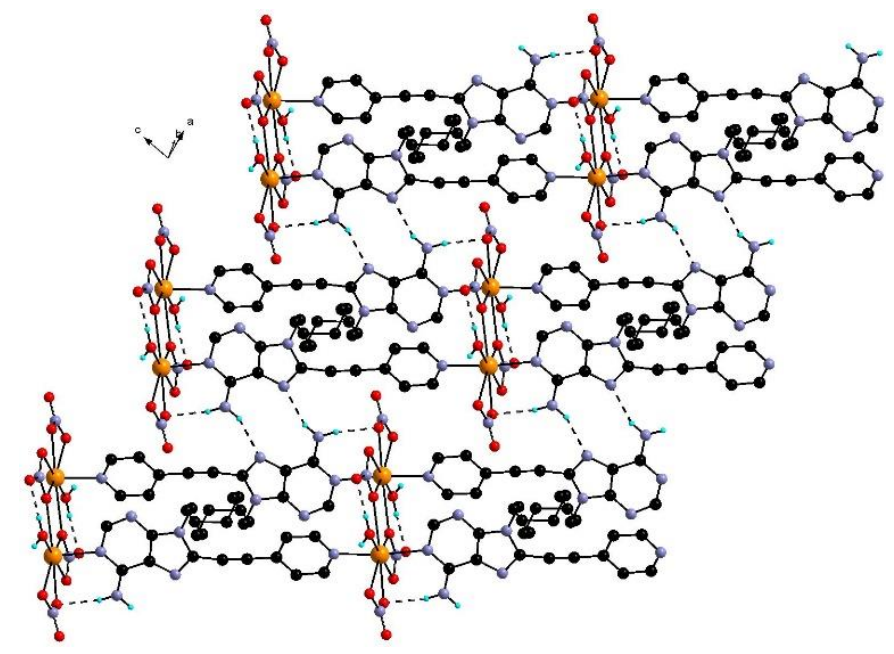

Fig. 11. Hydrogen bonding and coordination network in the structure of $\left[\left(\mathbf{C}_{6} \mathbf{A}-4 \mathrm{Py}\right)\right.$ $\left.\left(\mathrm{Cd}\left(\mathrm{NO}_{3}\right)_{2}\left(\mathrm{H}_{2} \mathrm{O}\right)\right)\right](1,2-\mathrm{DCE})$. C-H hydrogen atoms and 1-2-DCE molecules have been omitted for clarity.

\section{Conclusions}

A series of eight derivatives comprising, on one hand, either a 3- or 4-ethynylpyridine group and, on the other hand, a nucleobase has been designed, synthesized and characterized. In particular, in the crystalline state, these derivatives form self-complementary hydrogen bonding motifs. Furthermore, the ability of these compounds to form complementary base pairs has been explored and two such hetero-molecular assemblies have been characterized in the solid state, using cytosine and guaninebased species. These pairs feature the expected hydrogen bonding recognition pattern, as observed in natural systems. Not only are these compounds prone to hydrogen bonding but they have been also employed as tectons for the formation of coordination networks upon association with a series of metal salts. In $\left[\left(\mathrm{C}_{6} \mathrm{U}-4 \mathrm{Py}\right)_{2} \mathrm{Cu}(\mathrm{hfac})_{2}\right]$ and $\left[\left(\mathrm{C}_{6} \mathrm{C}-3 \mathrm{Py}\right)_{2} \mathrm{Cu}(\mathrm{OAC})_{2}\right]\left(\mathrm{H}_{2} \mathrm{O}\right)_{2}$, a similar $1 \mathrm{D}$ arrangement is observed resulting from coordination of the peripheral pyridyl group to the metal cations and selfcomplementary hydrogen bonding of the nucleobases. In these two cases, the latter are not involved in coordination unlike what is found in the other three networks obtained using the adenine-based tectons $\mathbf{C}_{6} \mathbf{A}-\mathbf{3 P y}$ and $\mathbf{C}_{6} \mathbf{A}-\mathbf{4 P y}$. For these networks, a recurrent self-complementary hydrogen bonding is found between the adenine moieties which also coordinate the metal cations via its N1 pyrimidinyl nitrogen atom. The peripheral pyridyl group is also bound to the metal centers. The dimensionality of these networks differs depending on the nature of the metal salt employed, the nuclearity of the metal node as well as position of the pyridyl unit. The foregoing results demonstrate the soundness as well as the complexity associated with the combination of nucleobases with coordinating units for the construction of molecular networks. While, in some cases, both binding events are clearly assigned each to a distinct functional moiety of the tectons with the pyridyl acting as a ligand and the nucleobase as a hydrogen bonding donor/acceptor, the tendency of the latter to also coordinate metal centers leads to more complex assemblies. One approach to circumvent this issue may consist in using two different tectons bearing complementary bases, thus potentially favouring hydrogen bonding at these sites, while the peripheral coordinating units may act as ligands towards metal cations. Future work will focus on the elaboration of such networks using nucleobase pairs 


\section{Experimental}

\section{Synthesis}

${ }^{1} \mathrm{H}$ - and ${ }^{13} \mathrm{C}$-NMR spectra were recorded at $25{ }^{\circ} \mathrm{C}$ on a Bruker AV500 (500 MHz) spectrometer with the deuterated solvent as the internal reference. NMR chemical shifts and $J$ values are given in parts per million ( $\mathrm{ppm}$ ) and in Hertz, respectively. Mass spectrometry was performed at the Service commun $d^{\prime}$ analyses of the University of Strasbourg. Starting materials 3- or 4-ethynylpyridine were prepared as described ${ }^{10}$, as well as iodo nucleobases $\mathbf{C}_{6} \mathbf{U}-\mathbf{I}$ and $\mathbf{C}_{6} \mathbf{C}-\mathbf{I},{ }^{9}$ and bromo derivatives $\mathbf{C}_{6} \mathbf{A}-\mathbf{B r},{ }^{11}$ and $\mathbf{C}_{6} \mathbf{G}-\mathbf{B r} .{ }^{9}$ All other reagents were obtained from commercial sources and used as received.

C $_{6}$ U-4Py: To a degassed solution of 1-hexyl-5-iodouracil $\mathbf{C}_{6} \mathrm{U}-\mathbf{I}(130 \mathrm{mg}, 0.4 \mathrm{mmol}, 1$ eq.) in DMF (6.2 $\mathrm{mL}$ ) and $\mathrm{Et}_{3} \mathrm{~N}(1.9 \mathrm{~mL})$ were added $\mathrm{Pd}\left(\mathrm{PPh}_{3}\right)_{2} \mathrm{Cl}_{2}(14 \mathrm{mg}, 20 \mu \mathrm{mol}, 0.05$ eq.), Cul (1.5 mg, $8 \mu \mathrm{mol}, 0.02$ eq.) and 4-ethynylpyridine ( $50 \mathrm{mg}, 0.5 \mathrm{mmol}, 1.2 \mathrm{eq}$.). The solution was stirred overnight at $50{ }^{\circ} \mathrm{C}$ under argon atmosphere. The solvents were evaporated under reduced pressure and the brown crude material was purified by column chromatography on silica gel $\left(\mathrm{CH}_{2} \mathrm{Cl}_{2}: \mathrm{MeOH}(99: 1)\right)$ to yield $\mathbf{C}_{6} \mathbf{U}-\mathbf{4 P y}$ as a pale yellow solid $(100 \mathrm{mg}, 83 \%) .{ }^{1} \mathrm{H}-\mathrm{NMR}\left(500 \mathrm{MHz}, \mathrm{CDCl}_{3}\right) \delta(\mathrm{ppm})=8.87(\mathrm{~s}, 1 \mathrm{H}), 8.60(\mathrm{~d}, J=4.3$ $\mathrm{Hz}, 2 \mathrm{H}$ ), $7.58(\mathrm{~s}, 1 \mathrm{H}), 7.37(\mathrm{~d}, J=4.3 \mathrm{~Hz}, 2 \mathrm{H}), 3.78(\mathrm{t}, J=7.4 \mathrm{~Hz}, 2 \mathrm{H}), 1.73$ (quint, $J=7.4 \mathrm{~Hz}, 2 \mathrm{H}$ ), $1.40-$ $1.31(\mathrm{~m}, 6 \mathrm{H}), 0.90(\mathrm{t}, J=6.7 \mathrm{~Hz}, 3 \mathrm{H}) .{ }^{13} \mathrm{C}-\mathrm{NMR}\left(125 \mathrm{MHz}, \mathrm{CDCl}_{3}\right) \delta(\mathrm{ppm})=161.3,149.7,149.6,147.9$, 131.0, 125.6, 99.1, 91.3, 85.1, 49.7, 31.4, 29.2, 26.2, 22.6, 14.1. HR-MS calculated for $\mathrm{C}_{17} \mathrm{H}_{20} \mathrm{~N}_{3} \mathrm{O}_{2}$ $[\mathrm{M}+\mathrm{H}]^{+}: 298.1550$, found: 298.1561

$\mathbf{C}_{6} \mathbf{C}-4 \mathrm{Py}$ : To a degassed solution of 1-hexyl-5-iodocytosine $\mathbf{C}_{6} \mathbf{C}-\mathbf{I}(130 \mathrm{mg}, 0.4 \mathrm{mmol}, 1$ eq.) in DMF (6.2 $\mathrm{mL}$ ) and $\mathrm{Et}_{3} \mathrm{~N}(1.9 \mathrm{~mL})$ were added $\mathrm{Pd}\left(\mathrm{PPh}_{3}\right)_{2} \mathrm{Cl}_{2}(14 \mathrm{mg}, 20 \mu \mathrm{mol}, 0.05$ eq.), Cul (1.5 mg, $8 \mu \mathrm{mol}, 0.02$ eq.) and 4-ethynylpyridine ( $50 \mathrm{mg}, 0.5 \mathrm{mmol}, 1.2$ eq.). The solution was stirred overnight at $55^{\circ} \mathrm{C}$ under an argon atmosphere. The solvents were evaporated under reduced pressure and the brown crude material was purified by column chromatography on silica gel $\left(\mathrm{CH}_{2} \mathrm{Cl}_{2}: \mathrm{MeOH}(98: 2)\right)$ to yield $\mathbf{C}_{6} \mathrm{C}-4 \mathbf{P y}$ as a pale yellow solid (91 mg, 76\%). ${ }^{1} \mathrm{H}-\mathrm{NMR}\left(500 \mathrm{MHz}, \mathrm{CDCl}_{3}\right) \delta(\mathrm{ppm})=8.60(\mathrm{dd}, J=4.4 \mathrm{~Hz}$ and 1.4 $\mathrm{Hz}, 2 \mathrm{H}), 7.69(\mathrm{~s}, 1 \mathrm{H}), 7.62(\mathrm{~s}, 1 \mathrm{H}), 7.30(\mathrm{dd}, J=4.4 \mathrm{~Hz}$ and $1.4 \mathrm{~Hz}, 2 \mathrm{H}), 5.74(\mathrm{br} \mathrm{s}, 2 \mathrm{H}), 3.79(\mathrm{t}, J=7.5 \mathrm{~Hz}$, $2 \mathrm{H}$ ), 1.72 (quint, $J=7.5 \mathrm{~Hz}, 2 \mathrm{H}$ ), $1.37-1.25(\mathrm{~m}, 6 \mathrm{H}), 0.87(\mathrm{t}, J=6.7 \mathrm{~Hz}, 3 \mathrm{H}) .{ }^{13} \mathrm{C}-\mathrm{NMR}\left(125 \mathrm{MHz}, \mathrm{CDCl}_{3}\right)$ $\delta(\mathrm{ppm})=164.3,154.8,150.1,149.3,130.4,125.1,93.1,89.7,84.8,51.0,31.5,29.4,26.4,22.6,14.1$. HR-MS calculated for $\mathrm{C}_{17} \mathrm{H}_{20} \mathrm{~N}_{4} \mathrm{OK}[\mathrm{M}+\mathrm{K}]^{+}: 335.1269$, found: 335.1257 . Crystals were obtained by slow diffusion of diethyl ether into a 1,2-dichloroethane solution of $\mathbf{C}_{6} \mathbf{C}-4 \mathrm{Py}$ (initial concentration $=10^{-2} \mathrm{M}$ ).

$\mathbf{C}_{6} \mathrm{~A}-4 \mathrm{Py}$ : To a degassed solution of 8-bromo-9-hexyladenine $\mathbf{C}_{6} \mathbf{A}-\mathbf{B r}(239 \mathrm{mg}, 0.8 \mathrm{mmol}, 1$ eq.) in DMF $(6.2 \mathrm{~mL})$ and $\mathrm{Et}_{3} \mathrm{~N}(1.9 \mathrm{~mL})$ were added $\mathrm{Pd}\left(\mathrm{PPh}_{3}\right)_{2} \mathrm{Cl}_{2}(28 \mathrm{mg}, 40 \mu \mathrm{mol}, 0.05 \mathrm{eq})$, Cul ( $3 \mathrm{mg}, 16 \mu \mathrm{mol}, 0.02$ eq.) and 4-ethynylpyridine ( $165 \mathrm{mg}, 1.6 \mathrm{mmol}, 2$ eq.). The solution was stirred overnight at $90{ }^{\circ} \mathrm{C}$ under an argon atmosphere. The solvents were evaporated under vacuum and the brown crude material was purified by column chromatography on silica gel $\left(\mathrm{CH}_{2} \mathrm{Cl}_{2}\right.$ : $\left.\mathrm{MeOH}(96: 4)\right)$ to yield $\mathbf{C}_{6} \mathrm{~A}-4 \mathrm{Py}$ as a pale yellow solid (165 mg, 64\%). ${ }^{1} \mathrm{H}-\mathrm{NMR}\left(500 \mathrm{MHz}, d_{7}\right.$-DMF) $\delta(\mathrm{ppm})=8.78(\mathrm{dd}, J=4.4 \mathrm{~Hz}$ and $1.6 \mathrm{~Hz}, 2 \mathrm{H})$, $8.28(\mathrm{~s}, 1 \mathrm{H}), 7.75(\mathrm{dd}, J=4.4 \mathrm{~Hz}$ and $1.6 \mathrm{~Hz}, 2 \mathrm{H}), 7.57(\mathrm{br} \mathrm{s}, 2 \mathrm{H}), 4.41(\mathrm{t}, J=7.0 \mathrm{~Hz}, 2 \mathrm{H}), 1.94$ (quint, $\mathrm{J}=$ $7.0 \mathrm{~Hz}, 2 \mathrm{H}), 1.39-1.22(\mathrm{~m}, 6 \mathrm{H}), 0.82(\mathrm{t}, J=7.1 \mathrm{~Hz}, 3 \mathrm{H}) .{ }^{13} \mathrm{C}-\mathrm{NMR}\left(125 \mathrm{MHz}, d_{7}-\mathrm{DMF}\right) \delta(\mathrm{ppm})=157.7$, $155.4,151.5,151.0,133.8,129.8,126.6,120.9,92.1,83.9,44.5,32.1,29.8,27.1,23.4,14.5$. HRMS calculated for $\mathrm{C}_{18} \mathrm{H}_{21} \mathrm{~N}_{6}[\mathrm{M}+\mathrm{H}]^{+}: 321.1822$, found: 321.1818 . 
C $_{6}$ G-4Py: To a degassed solution of 8-bromo-9-hexylguanine $\mathbf{C}_{6} \mathbf{G}-\mathbf{B r}(251 \mathrm{mg}, 0.8 \mathrm{mmol}, 1$ eq.) in DMF $(6.2 \mathrm{~mL})$ and $\mathrm{Et}_{3} \mathrm{~N}(1.9 \mathrm{~mL})$ were added $\mathrm{Pd}\left(\mathrm{PPh}_{3}\right)_{2} \mathrm{Cl}_{2}(28 \mathrm{mg}, 40 \mu \mathrm{mol}, 0.05 \mathrm{eq})$, Cul $(3 \mathrm{mg}, 16 \mu \mathrm{mol}, 0.02$ eq.) and 4-ethynylpyridine ( $165 \mathrm{mg}, 1.6 \mathrm{mmol}, 2$ eq.). The solution was stirred overnight at $90^{\circ} \mathrm{C}$ under argon atmosphere. The solvents were evaporated and the brown crude material was purified by column chromatography on silica gel $\left(\mathrm{CH}_{2} \mathrm{Cl}_{2}: \mathrm{MeOH}(95: 5)\right)$ to yield $\mathbf{C}_{6} \mathbf{G}-4 \mathrm{Py}$ as a pale yellow solid (160 $\mathrm{mg}, 60 \%) .{ }^{1} \mathrm{H}-\mathrm{NMR}\left(500 \mathrm{MHz}, d_{\sigma}\right.$-DMSO) $\delta(\mathrm{ppm})=10.77(\mathrm{~s}, 1 \mathrm{H}), 8.69(\mathrm{~d}, J=5.7 \mathrm{~Hz}, 2 \mathrm{H}), 7.60(\mathrm{~d}, J=5.7$ $\mathrm{Hz}, 2 \mathrm{H}), 6.68(\mathrm{br} \mathrm{s}, 2 \mathrm{H}), 4.09(\mathrm{t}, J=7.0 \mathrm{~Hz}, 2 \mathrm{H}), 1.76$ (quint, $J=7.0 \mathrm{~Hz}, 2 \mathrm{H}), 1.32-1.19(\mathrm{~m}, 6 \mathrm{H}), 0.79(\mathrm{t}, J$ $=7.0 \mathrm{~Hz}, 3 \mathrm{H}) .{ }^{13} \mathrm{C}-\mathrm{NMR}(125 \mathrm{MHz}, d 6-\mathrm{DMSO}) \delta(\mathrm{ppm})=156.3,154.4,151.3,150.2,128.9,128.7,125.1$, $117.7,89.9,83.4,42.7,30.7,29.0,25.6,22.0,13.8$. HRMS calculated for $\mathrm{C}_{18} \mathrm{H}_{21} \mathrm{~N}_{6} \mathrm{O}[\mathrm{M}+\mathrm{H}]^{+}: 337.1771$, found: 337.1764. Crystals were obtained by slow diffusion of diethyl ether into a 1,2-dichloroethane solution of $\mathbf{C}_{6} \mathbf{G}-\mathbf{4 P y}$ (initial concentration $=10^{-2} \mathrm{M}$ ).

C $_{6}$ U-3Py: To a degassed solution of 1-hexyl-5-iodouracil $\mathbf{C}_{6} \mathrm{U}-\mathbf{I}(314 \mathrm{mg}, 0.97 \mathrm{mmol}, 1$ eq.) in DMF (15 $\mathrm{mL}$ ) and $\mathrm{Et}_{3} \mathrm{~N}\left(4.5 \mathrm{~mL}\right.$ ) were added $\mathrm{Pd}\left(\mathrm{PPh}_{3}\right)_{2} \mathrm{Cl}_{2}(34 \mathrm{mg}, 50 \mu \mathrm{mol}, 0.05$ eq.), Cul (3.7 mg, $19 \mu \mathrm{mol}, 0.02$ eq.) and 3-ethynylpyridine $\left(100.5 \mathrm{mg}, 0.97 \mathrm{mmol}, 1\right.$ eq.). The solution was stirred overnight at $50{ }^{\circ} \mathrm{C}$ under argon atmosphere. After evaporation of the solvents, the brown crude material was purified by column chromatography $\left(\mathrm{CH}_{2} \mathrm{Cl}_{2}\right.$ : $\left.\mathrm{MeOH}(96: 4)\right)$ yielding $\mathrm{C}_{6} \mathrm{U}-3 \mathrm{Py}$ as a pale yellow solid ( $\left.251 \mathrm{mg}, 87 \%\right)$. ${ }^{1} \mathrm{H}-\mathrm{NMR}\left(500 \mathrm{MHz}, d_{6}\right.$-DMSO) $\delta(\mathrm{ppm})=11.68(\mathrm{~s}, 1 \mathrm{H}), 8.66(\mathrm{br} \mathrm{s}, 1 \mathrm{H}), 8.58(\mathrm{br} \mathrm{s}, 1 \mathrm{H}), 8.29(\mathrm{~s}, 1 \mathrm{H}), 7.88$ (d, $J=7.7 \mathrm{~Hz}, 1 \mathrm{H}), 7.45(\mathrm{dd}, J=7.7 \mathrm{~Hz}$ and $4.7 \mathrm{~Hz}, 1 \mathrm{H}), 7.36(\mathrm{dd}, J=4.31 \mathrm{~Hz}$ and $1.72 \mathrm{~Hz}, 2 \mathrm{H}), 3.70(\mathrm{t}, J$ $=7.2 \mathrm{~Hz}, 2 \mathrm{H}$ ), 1.60 (quint, $J=7.1 \mathrm{~Hz}, 2 \mathrm{H}), 1.32-1.21(\mathrm{~m}, 6 \mathrm{H}), 0.86(\mathrm{t}, J=6.7 \mathrm{~Hz}, 3 \mathrm{H}) .{ }^{13} \mathrm{C}-\mathrm{NMR}(125 \mathrm{MHz}$, $d_{6}$-DMSO) $\delta(\mathrm{ppm})=161.9,151.2,149.9,149.8,148.9,138.3,123.8,119.6,96.7,88.6,85.7,48.2,30.8$, 28.4, 25.4, 22.0, 13.9. HRMS calculated for $\mathrm{C}_{17} \mathrm{H}_{20} \mathrm{~N}_{3} \mathrm{O}_{2}[\mathrm{M}+\mathrm{H}]^{+}: 298.1550$, found: 298.1555 .

C $_{6}$ C-3Py: To a degassed solution of 1-hexyl-5-iodocytosine $\mathbf{C}_{6} \mathbf{C}-\mathbf{I}$ (103 mg, $0.32 \mathrm{mmol}, 1$ eq.) in DMF (3 $\mathrm{mL}$ ) and $\mathrm{Et}_{3} \mathrm{~N}(1.5 \mathrm{~mL})$ were added $\mathrm{Pd}\left(\mathrm{PPh}_{3}\right)_{2} \mathrm{Cl}_{2}(10 \mathrm{mg}, 15 \mu \mathrm{mol}, 0.05$ eq.), Cul (1.1 mg, $6 \mu \mathrm{mol}, 0.02$ eq.) and 3-ethynylpyridine ( $33 \mathrm{mg}, 0.32 \mathrm{mmol}, 1$ eq.). The solution was stirred overnight at $50{ }^{\circ} \mathrm{C}$ under an argon atmosphere. The solvents were evaporated and the crude material was purified by column chromatography on silica gel $\left(\mathrm{CH}_{2} \mathrm{Cl}_{2}\right.$ : $\left.\mathrm{MeOH}(94: 6)\right)$ yielding $\mathrm{C}_{6} \mathrm{C}-3 \mathrm{Py}$ as a pale yellow solid $(79 \mathrm{mg}$, 83\%). ${ }^{1} \mathrm{H}-\mathrm{NMR}\left(500 \mathrm{MHz}, d_{6}\right.$-DMSO) $\delta(\mathrm{ppm})=8.77(\mathrm{br} \mathrm{s}, 1 \mathrm{H}), 8.54(\mathrm{br} \mathrm{s}, 1 \mathrm{H}), 8.20(\mathrm{~s}, 1 \mathrm{H}), 7.99(\mathrm{~d}, J=$ $8.0 \mathrm{~Hz}, 1 \mathrm{H}), 7.68(\mathrm{~s}, 1 \mathrm{H}), 7.44(\mathrm{dd}, J=8.0 \mathrm{~Hz}$ and $5.1 \mathrm{~Hz}, 1 \mathrm{H}), 7.36(\mathrm{dd}, J=4.31 \mathrm{~Hz}$ and $1.72 \mathrm{~Hz}, 2 \mathrm{H}), 3.68$ $(\mathrm{t}, J=7.3 \mathrm{~Hz}, 2 \mathrm{H}$ ), 1.58 (quint, $J=6.9 \mathrm{~Hz}, 2 \mathrm{H}), 1.31-1.21(\mathrm{~m}, 6 \mathrm{H}), 0.86(\mathrm{t}, J=6.4 \mathrm{~Hz}, 3 \mathrm{H}) .{ }^{13} \mathrm{C}-\mathrm{NMR}(125$ $\mathrm{MHz}, d_{6}$-DMSO) $\delta(\mathrm{ppm})=164.0,154.0,151.4,150.4,148.5,138.2,123.4,119.8,90.8,88.1,84.9,49.1$, $30.9,28.6,25.6,22.0,13.9$. HRMS calculated for $\mathrm{C}_{17} \mathrm{H}_{21} \mathrm{~N}_{4} \mathrm{O}[\mathrm{M}+\mathrm{H}]^{+}: 297.1710$, found: 297.1698. $\mathrm{C}_{6} \mathrm{C}-$ $3 \mathrm{Py}_{2} \mathrm{O}$ crystals (triclinic, $P$-1) were obtained upon slow evaporation of a solution of the compound in $\mathrm{CHCl}_{3} / \mathrm{MeOH}\left(5: 1\right.$, initial concentration $\left.=10^{-2} \mathrm{M}\right)$.

C $_{6}$ A-3Py: To a degassed solution of 8-bromo-9-hexyladenine $\mathbf{C}_{6} \mathrm{~A}-\mathrm{Br}(260.2 \mathrm{mg}, 0.87 \mathrm{mmol}, 1$ eq.) in $\operatorname{DMF}(9 \mathrm{~mL})$ and $\mathrm{Et}_{3} \mathrm{~N}(4.5 \mathrm{~mL})$ were added $\mathrm{Pd}\left(\mathrm{PPh}_{3}\right)_{2} \mathrm{Cl}_{2}(30.6 \mathrm{mg}, 44 \mu \mathrm{mol}, 0.05 \mathrm{eq}), \mathrm{Cul}(3.3 \mathrm{mg}, 17$ $\mu \mathrm{mol}, 0.02$ eq.) and 3-ethynylpyridine $(90 \mathrm{mg}, 0.87 \mathrm{mmol}, 1$ eq.). The solution was stirred overnight at $50{ }^{\circ} \mathrm{C}$ under an argon atmosphere. The solvents were evaporated and the crude material was purified by column chromatography on silica gel $\left(\mathrm{CH}_{2} \mathrm{Cl}_{2}\right.$ : MeOH (93: 7) yielding $\mathrm{C}_{6} \mathrm{~A}-3 \mathrm{Py}$ as a pale yellow solid (206 mg, 74\%). ${ }^{1} \mathrm{H}-\mathrm{NMR}\left(500 \mathrm{MHz}, d_{\sigma}\right.$-DMSO) $\delta(\mathrm{ppm})=8.89(\mathrm{br} \mathrm{s}, 1 \mathrm{H}), 8.70(\mathrm{~d}, J=5.2 \mathrm{~Hz}, 1 \mathrm{H}), 8.20(\mathrm{~s}$, $1 \mathrm{H}), 8.13(\mathrm{~d}, J=7.8 \mathrm{~Hz}, 1 \mathrm{H}), 7.53(\mathrm{dd}, J=5.2 \mathrm{~Hz}$ and $7.6 \mathrm{~Hz}, 1 \mathrm{H}), 7.52(\mathrm{br} \mathrm{s}, 2 \mathrm{H}), 4.30(\mathrm{t}, J=7.0 \mathrm{~Hz}, 2 \mathrm{H})$, 1.84 (quint, $J=6.6 \mathrm{~Hz}, 2 \mathrm{H}$ ), $1.33-1.18(\mathrm{~m}, 6 \mathrm{H}), 0.77(\mathrm{t}, J=7.2 \mathrm{~Hz}, 3 \mathrm{H}) .{ }^{13} \mathrm{C}-\mathrm{NMR}\left(125 \mathrm{MHz}, d_{6}-\mathrm{DMSO}\right)$ $\delta(\mathrm{ppm})=156.3,154.3,151.7,151.3,149.8,138.7,129.3,123.9,118.3,117.4,89.5,82.4,42.8,30.7$, 
29.0, 25.6, 22.0, 13.8. HRMS calculated for $\mathrm{C}_{18} \mathrm{H}_{21} \mathrm{~N}_{6}[\mathrm{M}+\mathrm{H}]^{+}:$321.1822, found: $321.1830 . \mathrm{C}_{6} \mathrm{~A}-3 \mathrm{Py}(1,2-$ DCE) crystals (triclinic, $P-1$ ) were obtained by slow evaporation of a 1,2-DCE/MeOH (5:1) solution of the compound (initial concentration $=10^{-2} \mathrm{M}$ ).

$\mathbf{C}_{6}$ G-3Py: To a degassed solution of 8-bromo-9-hexylguanine $\mathbf{C}_{6} \mathbf{G}-\mathbf{B r}$ ( $274 \mathrm{mg}, 0.87 \mathrm{mmol}, 1$ eq.) in DMF $(9 \mathrm{~mL})$ and $\mathrm{Et}_{3} \mathrm{~N}(4.5 \mathrm{~mL})$ were added $\mathrm{Pd}\left(\mathrm{PPh}_{3}\right)_{2} \mathrm{Cl}_{2}(30 \mathrm{mg}, 44 \mu \mathrm{mol}, 0.05 \mathrm{eq})$, Cul $(3.3 \mathrm{mg}, 17 \mu \mathrm{mol}, 0.02$ eq.) and 3-ethynylpyridine ( $90 \mathrm{mg}, 0.87 \mathrm{mmol}, 1$ eq.). The solution was stirred overnight at $50{ }^{\circ} \mathrm{C}$ under argon atmosphere. The solvents were evaporated and the crude material was purified by column chromatography on silica gel $\left(\mathrm{CH}_{2} \mathrm{Cl}_{2}: \mathrm{MeOH}(91: 9)\right)$ yielding $\mathbf{C}_{6} \mathbf{G}-3 \mathbf{P y}$ as a pale yellow solid $(213 \mathrm{mg}$, 73\%). ${ }^{1} \mathrm{H}-\mathrm{NMR}\left(500 \mathrm{MHz}, d_{6}\right.$-DMSO) $\delta(\mathrm{ppm})=10.75(\mathrm{~s}, 1 \mathrm{H}), 8.87(\mathrm{br} \mathrm{s}, 1 \mathrm{H}), 8.69(\mathrm{br} \mathrm{s}, 1 \mathrm{H}), 8.07(\mathrm{~d}, J=$ $7.8 \mathrm{~Hz}, 1 \mathrm{H}$ ), $7.54(\mathrm{dd}, J=4.6 \mathrm{~Hz}$ and $7.8 \mathrm{~Hz}, 1 \mathrm{H}), 6.66(\mathrm{br} \mathrm{s}, 2 \mathrm{H}), 4.09(\mathrm{t}, J=7.1 \mathrm{~Hz}, 2 \mathrm{H}), 1.76$ (quint $J=$ $6.6 \mathrm{~Hz}, 2 \mathrm{H}), 1.35-1.18(\mathrm{~m}, 6 \mathrm{H}), 0.78(\mathrm{t}, J=7.0 \mathrm{~Hz}, 3 \mathrm{H}) .{ }^{13} \mathrm{C}-\mathrm{NMR}\left(125 \mathrm{MHz}, d_{6}\right.$-DMSO) $\delta(\mathrm{ppm})=156.0$, 153.9, 152.0, 150.3, 149.3, 139.1, 132.6, 123.9, 119.1, 117.6, 90.7, 81.8, 43.0, 30.6, 29.0, 25.6, 21.9, 13.8. HRMS calculated for $\mathrm{C}_{18} \mathrm{H}_{21} \mathrm{~N}_{6} \mathrm{O}[\mathrm{M}+\mathrm{H}]^{+}: 337.1771$, found: $337.1770 . \mathrm{C}_{6} \mathrm{G}-3 P y$ crystals (monoclinic, $P 2_{1} / c$ ) were obtained upon vapour diffusion of $\mathrm{MeOH}$ into a $\mathrm{CHCl}_{3}$ solution of the functionalized nucleobase (initial concentration $=10^{-2} \mathrm{M}$ ).

$\mathbf{C}_{6} \mathbf{G}-3$ Py $\cdot \mathbf{C}_{6} \mathrm{C}-3 \mathbf{P P y}(\mathrm{MeOH})_{2}$ : Slow evaporation of $\mathrm{CH}_{2} \mathrm{Cl}_{2} / \mathrm{MeOH}(5 / 1)$ solution of $\mathbf{C}_{6} \mathbf{G}-3 \mathbf{P y}(5 \mathrm{mg}, 0.015$ $\mathrm{mmol}$ ) and $\mathbf{C}_{6} \mathrm{C}-3 \mathrm{Py}(4.4 \mathrm{mg}, 0.015 \mathrm{mmol})$ afforded the cocrystals after few days. Elemental analysis calculated for $\mathrm{C}_{37} \mathrm{H}_{48} \mathrm{~N}_{10} \mathrm{O}_{4} \mathrm{C}, 63.77 ; \mathrm{H}, 6.94 ; \mathrm{N}, 20.10$. Found C, 60.68; $\mathrm{H}, 6.51 ; \mathrm{N}, 20.22$.

$\mathbf{C}_{6} \mathbf{G}-4$ Py $\cdot \mathbf{C}_{6} \mathbf{C}-4 \mathrm{Py}$ : Slow vapour diffusion of $\mathrm{Et}_{2} \mathrm{O}$ in a mixture of $\mathbf{C}_{6} \mathbf{G}-4 \mathrm{Py}(5 \mathrm{mg}, 0.015 \mathrm{mmol})$ and $\mathbf{C}_{6} \mathbf{C}-$ 4Py $(4.4 \mathrm{mg}, 0.015 \mathrm{mmol})$ in 1,2-DCE (14 mL) afforded the desired cocrystals as white product $(5.4 \mathrm{mg})$. Elemental analysis calculated for $\mathrm{C}_{35} \mathrm{H}_{40} \mathrm{~N}_{10} \mathrm{O}_{2} \mathrm{C}, 66.43 ; \mathrm{H}, 6.37 ; \mathrm{N}, 22.13$. Found $\mathrm{C}, 65.47 ; \mathrm{H}, 6.20 ; \mathrm{N}$, 21.61.

[( $\left.\left.\mathbf{C}_{6} \mathbf{U}-4 \mathrm{Py}\right)_{2} \mathrm{Cu}(\mathrm{hfac})_{2}\right] .(1,2-\mathrm{DCE})_{2}:$ A mixture of a 1,2-DCE $(1.6 \mathrm{~mL})$ solution of $\mathbf{C}_{6} \mathbf{U}-4 \mathrm{Py}(5 \mathrm{mg}, 0.017$ $\mathrm{mmol})$ and a $\mathrm{MeOH}(1 \mathrm{~mL})$ solution of $\mathrm{Cu}(\mathrm{hfac})_{2}(4 \mathrm{mg}, 0.008 \mathrm{mmol})$ was left to slowly evaporate at room temperature to afford green crystals $(3.5 \mathrm{mg})$. Elemental analysis calculated for $\mathrm{C}_{44} \mathrm{H}_{40} \mathrm{CuF}_{12} \mathrm{~N}_{6} \mathrm{O}_{8}$ $\mathrm{C}, 49.28 ; \mathrm{H}, 3.76 ; \mathrm{N}, 7.83$. Found $\mathrm{C}, 49.54 ; \mathrm{H}, 4.11 ; \mathrm{N}, 7.49$. This indicates solvent loss upon removal from the mother liquor.

$\left[\left(\mathrm{C}_{6} \mathrm{C}-3 \mathrm{Py}\right)_{2}\left(\mathrm{Cu}(\mathrm{OAC})_{2}\right)_{2}\right]\left(\mathrm{H}_{2} \mathrm{O}\right)_{2}:$ A 1,2-DCE solution (1.7 mL) of $\mathrm{C}_{6} \mathrm{C}-3 \mathrm{Py}(5 \mathrm{mg}, 0.017 \mathrm{mmol})$ was added to a $\mathrm{MeCN}(1.7 \mathrm{~mL})$ solution of $\mathrm{Cu}(\mathrm{OAc})_{2}\left(\mathrm{H}_{2} \mathrm{O}\right)(3.3 \mathrm{mg}, 0.017 \mathrm{mmol})$. The green solution was left to evaporate slowly at room temperature to afford green crystals $(5.0 \mathrm{mg})$. Elemental analysis calculated for $\mathrm{C}_{42} \mathrm{H}_{56} \mathrm{Cu}_{2} \mathrm{~N}_{8} \mathrm{O}_{12} \mathrm{C}, 50.85 ; \mathrm{H}, 5.69 ; \mathrm{N}, 11.29$. Found $\mathrm{C}, 50.16 ; \mathrm{H}, 5.62 ; \mathrm{N}, 11.16$.

[( $\left.\left.\mathrm{C}_{6} \mathrm{~A}-3 \mathrm{Py}\right) \mathrm{Cu}(\mathrm{hfac})_{2}\right]\left(\mathrm{H}_{2} \mathrm{O}\right): \mathrm{A} \mathrm{MeOH}(1 \mathrm{~mL})$ solution of $\mathrm{Cu}(\mathrm{hfac})_{2}(3.7 \mathrm{mg}, 0.008 \mathrm{mmol})$ was added to a solution of $\mathbf{C}_{6} \mathbf{A}-3 \mathrm{Py}$ ( $\left.5 \mathrm{mg}, 0.016 \mathrm{mmol}\right)$ in 1,2-DCE/MeOH (5:1) solution $(1.5 \mathrm{~mL})$. The mixture was left to evaporate slowly to afford green crystals of the assembly $(7.7 \mathrm{mg})$. Elemental analysis calculated for $\mathrm{C}_{28} \mathrm{H}_{24} \mathrm{CuF}_{12} \mathrm{~N}_{6} \mathrm{O}_{5} \mathrm{C}, 41.21 ; \mathrm{H}, 2.96 ; \mathrm{N}, 10.29$. Found $\mathrm{C}, 41.00 ; \mathrm{H}, 2.88 ; \mathrm{N}, 10.01$. 
[( $\left.\left.\mathbf{C}_{6} \mathbf{A}-3 \mathrm{Py}\right)_{2} \mathrm{Cd}\left(\mathrm{NO}_{3}\right)_{2}\right](1,2-\mathrm{DCE})_{0.5}(\mathrm{MeOH})$ : A solution of $\mathbf{C}_{6} \mathrm{~A}-3 \mathrm{Py}(5 \mathrm{mg}, 0.016 \mathrm{mmol})$ in 1,2-DCE/MeOH $(5: 1)(1.6 \mathrm{~mL})$ was added to a MeCN solution $(3.2 \mathrm{~mL})$ of $\mathrm{Cd}\left(\mathrm{NO}_{3}\right)_{2}\left(\mathrm{H}_{2} \mathrm{O}\right)_{4}(2.4 \mathrm{mg}, 0.008 \mathrm{mmol})$. Slow evaporation afforded colourless crystals of the assembly $(3.5 \mathrm{mg})$. Elemental analysis calculated for $\mathrm{C}_{38} \mathrm{H}_{46} \mathrm{CdClN}_{14} \mathrm{O}_{7} \mathrm{C}, 47.60 ; \mathrm{H}, 4.83 ; \mathrm{N}, 20.45$. Found $\mathrm{C}, 46.74 ; \mathrm{H}, 4.44 ; \mathrm{N}, 21.30$. This indicates partial desolvation by loss of 1,2-DCE.

[( $\left.\left.\mathrm{C}_{6} \mathrm{~A}-4 \mathrm{Py}\right)\left(\mathrm{Cd}\left(\mathrm{NO}_{3}\right)_{2}\left(\mathrm{H}_{2} \mathrm{O}\right)\right)\right](1,2-\mathrm{DCE})$ : A solution of $\mathrm{C}_{6} \mathrm{~A}-4 \mathrm{Py}(5 \mathrm{mg}, 0.016 \mathrm{mmol})$ in 1,2-DCE/MeOH (5:1) $(1.6 \mathrm{~mL})$ was added to a MeCN solution $(3.2 \mathrm{~mL})$ of $\mathrm{Cd}\left(\mathrm{NO}_{3}\right)_{2}\left(\mathrm{H}_{2} \mathrm{O}\right)_{4}(4.8 \mathrm{mg}, 0.016 \mathrm{mmol})$. Upon slow evaporation, crystals of the assembly were obtained $(3.3 \mathrm{mg})$. Elemental analysis calculated for $\mathrm{C}_{20} \mathrm{H}_{26} \mathrm{CdCl}_{2} \mathrm{~N}_{8} \mathrm{O}_{7} \mathrm{C}, 35.65 ; \mathrm{H}, 3.89 ; \mathrm{N}, 16.63$. Found $\mathrm{C}, 36.77 ; \mathrm{H}, 3.88 ; \mathrm{N}, 18.49$.

\section{X-ray crystallography}

Data (Tables 1-3) were collected on a Bruker SMART CCD diffractometer with Mo-Ka radiation at 173 $\mathrm{K}$ for all compounds. The structures were solved using SHELXS-97 and refined by full matrix leastsquares on $F^{2}$ using SHELXL-2014 with anisotropic thermal parameters for all non-hydrogen atoms. ${ }^{17}$ Hydrogen atoms were introduced at calculated positions and refined using the riding model. In the structures of $\left[\mathrm{C}_{6} \mathrm{C}-3 \mathrm{Py} \mathrm{H}_{2} \mathrm{O}\right]_{3}$ and $\mathbf{C}_{6} \mathrm{G}-4 \mathbf{P y} \cdot \mathbf{C}_{6} \mathrm{C}-4 \mathrm{Py}$, the $n$-hexyl chains show positional disorder that has been modelled over two positions. In the structure of $\mathbf{C}_{6} \mathbf{G}-4 \mathbf{P y}$ and $\left[\left(\mathbf{C}_{6} \mathbf{A}-\mathbf{3 P y}\right)_{2} \mathrm{Cd}\left(\mathrm{NO}_{3}\right)_{2}\right](1,2-$ $\mathrm{DCE})_{0.5}(\mathrm{MeOH})$, highly disorder solvent molecules are present. The SQUEEZE command has been applied to account for the corresponding electronic density. ${ }^{18}$

The X-ray powder patterns for compounds that did not show desolvation are showed in ESI (Figs. ESI4144).

\section{Conflicts of interest}

There are no conflicts to declare.

\section{Acknowledgements}

We thank the University of Strasbourg, the C.N.R.S., the International centre for Frontier Research in Chemistry (icFRC), the Labex CSC within the Investissement d'Avenir program ANR-10-IDEX-0002-02, the IdEx programme of the University of Strasbourg and the Ministère de l'Enseignement Supérieur, de la Recherche et de l'Innovation for financial support.

\section{References}

1 a) M. Simard, D. Su and J. D. Wuest, J. Am. Chem. Soc., 1991, 113, 4696. b) S. Mann, Nature, 1993, 365, 499. c) M. W. Hosseini, Acc. Chem. Res., 2005, 38, 313. d) J. D. Wuest, Chem. Commun., 2005, 5830.

2 T. Steiner, Angew. Chem. Int. Ed., 2002, 41, 48.

3 a) S. Sivakova and S. J. Rowan, Chem. Soc. Rev., 2005, 34, 9. b) J. L. Sessler, C. M. Lawrence and J. Jayawickramajah, Chem. Soc. Rev., 2007, 36, 314. c) I. Hirao, M. Kimoto and R. Yamashige, Acc. Chem. Res., 2012, 45, 2055. d) I. Isaki, C. Xin, K. Takahashi and T. Nakamura, Angew. Chem. Int. Ed., 2019, 58, 11160.

4 a) T. R. Cook, Y.-R. Zhao and P. J. Stang, Chem. Rev., 2013, 113, 734. b) H. C. Zhou, J. R. Long and O. M. Yaghi, Chem. Rev., 2012, 112, 673, Metal-Organic Frameworks special issue. c) H. C. J. Zhou and S. Kitagawa, Chem. Soc. Rev., 2014, 43, 5415, themed issue on metal-organic frameworks. 
5 a) A. Beatty, Coord. Chem. Rev., 2003, 246, 131. b) L. Brammer, CrystEngComm., 2004, 33, 476. c) S. Kitagawa and K. Uemura, Chem. Soc. Rev., 2005, 34, 109. d) J. Reedijk, Chem. Soc. Rev., 2013, 42, 1776. e) B. Therrien, Chemistry, 2020, 2, 565.

6 a) S. Verma, A. Kumar Mishra and J. Kumar, Acc. Chem. Res., 2010, 43, 79. b) Y. Takezawa and M. SHionoya, Acc. Chem. Res., 2012, 45, 2066. c) G. Beobide, O. Castillo, J. Cepeda, A. Luque, S. PérezYáñez, P. Román and J. Thomas-Gipson, Coord. Chem. Rev., 2013, 257, 2716. d) P. Amo-Ochoa and F. Zamora, Coord. Chem. Rev., 2014, 276, 34. e) G. Beobide, O. Castillo, A. Luque and S. Pérez-Yáñez, CrystEngComm, 2015, 17, 3051. f) B. Lippert and P. J. Sanz-Miguel, Acc. Chem. Res., 2016, 49, 1537. g) B. Mohapatra, Pratibha and S. Verma, CrystEngComm., 2017, 53, 4748. h) A. Lopez and J. Liu, ChemNanoMat, 2017, 3, 670. i) J. Müller, Coord. Chem. Rev., 2019, 393, 37.

7 a) M. Nakaya, R. Ohtani, K. Sugimoto, M. Nakamura, L. F. Lindoy and S. Hayami, Chem. Eur.J., 2017, 23, 7232. b) K. Hassanein, O. Castillo, C. J. Gómez-Garcia, F. Zamora and P. Amo-Ochoa, Cryst. Growth Des., 2015, 15, 5485. c) K. Kagesawa, Y. Ichikawa, H. Iguchi, B. K. Breedlove, Z. Li, M. Yamashita, A. Okazawa, W. Kosaka and H. Miyasaka, Chem. Lett., 2019, 48, 1221. d) Q. Shi, X. Zhou, W. Yuan, X. Su, A. Neniškis, X. Wei, L. Taujenis, G. Snarskis, J. S. Ward, K. Rissanen, J. de Mendoza and E. Orentas, J. Am. Chem. Soc., 2020, 142, 3658.

8 E. Tufenkijan, A. Jouaiti, N. Kyritsakas, M. W. Hosseini and V. Bulach, Tetrahedron, 2020, 76, 130966.

9 N. Bilbao, V. Vázquez-González, M. T. Aranda and D. González-Rodríguez, Eur. J. Org. Chem., 2015, 7160 .

10 L. Yu and J. S. Lindsey, J. Org. Chem., 2001, 66, 7402.

11 E. Coutouli-Argyropoulou, M. Tsitabani, G. Petrantonakis, A. Terzis and C. Raptopoulou, Org. Biomol. Chem., 2003, 1, 1382.

12 Y.-L. Wu, K. E. Brown and M. R. Wasielewski, J. Am. Chem. Soc., 2013, 135, 13322.

13 a) A. Marsh, N. W. Alcock, W. Errington and R. Sagar, Tetrahedron, 2003, 59, 5595. b) E. Miyazaki, Y. Morita, Y. Yakiyama, S. Maki, Y. Umemoto, M. Ohmoto and K. Nakasuji, Chem. Lett., 2007, 36, 1102. c) F. Seela, S. Budow, H. Eickmeier and H. Reuter, Acta Cryst., 2007, C63, 054. d) D. W. Dodd, K. N. Swanick, J. T. Price, A. L. Brazeau, M. J. Ferguson, N. D. Jones and R. H. E. Hudson, Org. Biomol. Chem., 2010, 8, 663. e) T. Murata, E. Miyazaki, K. Nakasuji and Y. Morita, Cryst. Growth Des., 2012, 12, 5815. f) P. Mombelli, C. Le Chapelain, N. Munzinger, E. Joliat, B. Illarionov, W. B. Schweizer, A. K. H. Hirsch, M. Fischer, A. Bacher and F. Diederich, Eur. J. Org. Chem., 2013, 1068.

14 J. Lim and O. Š. Miljanic, CrystEngComm, 2011, 13, 5309.

15 a) H. M. Sobell, K. I. Tomita and A. Rich, Proc. Natl. Acad. Sci. U. S. A., 1963, 49, 885. b) E. J. O’Brien, Acta Cryst., 1967, 23, 92. c) T. Stolar, S. Lukin, M. Etter, M. R. Linarić, K. Užarević, E. Meštrović and I. Halasz, Chem. Commun., 2020, 56, 13524.

16 J. Šponer, P. Jurečka, and P. Hobza, J. Am. Chem. Soc., 2004, 126, 10142.

17 G. M. Sheldrick, Acta Cryst. C, 2015, 71, 3.

18 A. L. Spek, PLATON, The University of Utrecht, Utrecht, The Netherlands, 1999. 
Table 1 Crystallographic data for the free nucleobases.

\begin{tabular}{|c|c|c|c|c|c|}
\hline & {$\left[\mathrm{C}_{6} \mathrm{C}-3 \mathrm{Py} \mathrm{H} \mathrm{H}_{2} \mathrm{O}\right]_{3}$} & $\mathrm{C}_{6} \mathrm{C}-4 \mathrm{Py}$ & $\mathrm{C}_{6} \mathrm{G}-3 \mathrm{Py}$ & {$\left[\mathrm{C}_{6} \mathrm{G}-4 \mathrm{Py}\right]_{4}$} & $\mathrm{C}_{6} \mathrm{~A}-3 \mathrm{Py}(1,2-\mathrm{DCE})$ \\
\hline Formula & $\mathrm{C}_{51} \mathrm{H}_{66} \mathrm{~N}_{12} \mathrm{O}_{6}$ & $\mathrm{C}_{17} \mathrm{H}_{20} \mathrm{~N}_{4} \mathrm{O}$ & $\mathrm{C}_{18} \mathrm{H}_{20} \mathrm{~N}_{6} \mathrm{O}$ & $\mathrm{C}_{72} \mathrm{H}_{80} \mathrm{~N}_{24} \mathrm{O}_{4}$ & $\mathrm{C}_{20} \mathrm{H}_{24} \mathrm{~N}_{6} \mathrm{Cl}_{2}$ \\
\hline FW & 943.15 & 296.37 & 336.40 & 1345.60 & 419.35 \\
\hline Crystal system & Triclinic & Monoclinic & Monoclinic & Triclinic & Triclinic \\
\hline Space group & $P-1$ & $P 2_{1} / c$ & $P 2_{1} / c$ & $P-1$ & $P-1$ \\
\hline$a / \AA$ & $11.9317(6)$ & $13.2843(10)$ & $9.3898(5)$ & $11.5373(5)$ & $8.0332(3)$ \\
\hline$b / \AA$ & $14.0535(8)$ & $9.9419(6)$ & $11.5181(6)$ & $18.3921(10)$ & $10.5895(5)$ \\
\hline$c / \AA$ & $15.9543(9)$ & $13.1958(11)$ & $16.5570(7)$ & $19.7362(10)$ & $13.0038(7)$ \\
\hline$\alpha /{ }^{\circ}$ & $97.164(2)$ & & & $105.323(2)$ & $90.712(2)$ \\
\hline$\beta /{ }^{\circ}$ & $105.719(2)$ & $115.219(3)$ & $98.597(2)$ & $101.496(2)$ & $91.103(2)$ \\
\hline$\gamma /{ }^{\circ}$ & $97.882(2)$ & & & $106.603(2)$ & $105.311(2)$ \\
\hline$V / \AA^{3}$ & $2513.9(2)$ & $1576.7(2)$ & $1770.56(15)$ & $3695.6(3)$ & $1066.57(9)$ \\
\hline$Z$ & 2 & 4 & 4 & 2 & 2 \\
\hline$T / K$ & $173(2)$ & $173(2)$ & $173(2)$ & $173(2)$ & $173(2)$ \\
\hline$\mu / \mathrm{mm}^{-1}$ & 0.084 & 0.081 & 0.083 & 0.080 & 0.322 \\
\hline Refls. coll. & 17746 & 11119 & 57755 & 47301 & 16152 \\
\hline Ind. refls. ( $\left.R_{\text {int }}\right)$ & $9576(0.0356)$ & $4601(0.0325)$ & $4879(0.0424)$ & $16190(0.0377)$ & $4604(0.0307)$ \\
\hline$R_{1}(1>2 \sigma(I))^{\mathrm{a}}$ & 0.0628 & 0.0700 & 0.0459 & 0.0596 & 0.0965 \\
\hline$w R_{2}(I>2 \sigma(I))^{a}$ & 0.1625 & 0.1938 & 0.1292 & 0.1595 & 0.2653 \\
\hline$R_{1}$ (all data) $^{\mathrm{a}}$ & 0.1001 & 0.0932 & 0.0561 & 0.0834 & 0.1210 \\
\hline$w R_{2}$ (all data) $^{\mathrm{a}}$ & 0.1912 & 0.2175 & 0.1396 & 0.1772 & 0.2925 \\
\hline GOF & 1.029 & 1.026 & 1.044 & 1.018 & 1.029 \\
\hline
\end{tabular}


Table 2 Crystallographic data for base pairs $\mathrm{C}_{6} \mathrm{G}-3 \mathrm{Py} \cdot \mathrm{C}_{6} \mathrm{C}-3 \mathrm{Py}(\mathrm{MeOH})_{2}$. and $\mathrm{C}_{6} \mathrm{G}-4 \mathrm{Py} \cdot \mathrm{C}_{6} \mathrm{C}-4 \mathrm{Py}$.

$\mathrm{C}_{6} \mathrm{G}-3 \mathrm{Py} \cdot \mathrm{C}_{6} \mathrm{C}-3 \mathrm{Py}(\mathrm{MeOH})_{2} \quad \mathrm{C}_{6} \mathrm{G}-4 \mathrm{Py} \cdot \mathrm{C}_{6} \mathrm{C}-4 \mathrm{Py}$

\begin{tabular}{|c|c|c|}
\hline Formula & $\mathrm{C}_{37} \mathrm{H}_{48} \mathrm{~N}_{10} \mathrm{O}_{4}$ & $\mathrm{C}_{35} \mathrm{H}_{40} \mathrm{~N}_{10} \mathrm{O}_{2}$ \\
\hline FW & 696.85 & 632.77 \\
\hline Crystal system & Triclinic & Monoclinic \\
\hline Space group & $P-1$ & $P 2_{1} / c$ \\
\hline$a / \AA$ & $8.4429(6)$ & $8.3993(3)$ \\
\hline$b / \AA$ & $15.7140(9)$ & $18.1256(7)$ \\
\hline$c / \AA$ & $16.1715(8)$ & $21.8533(8)$ \\
\hline$\alpha /^{\circ}$ & $112.591(2)$ & \\
\hline$\beta /^{\circ}$ & $104.239(2)$ & $92.942(2)$ \\
\hline$\gamma /^{\circ}$ & $95.640(3)$ & \\
\hline$V / \AA^{3}$ & $1874.9(2)$ & $3322.6(2)$ \\
\hline$Z$ & 2 & 4 \\
\hline$T / \mathrm{K}$ & $173(2)$ & $173(2)$ \\
\hline$\mu / \mathrm{mm}^{-1}$ & 0.083 & 0.083 \\
\hline Refls. coll. & 31016 & 23116 \\
\hline Ind. refls. $\left(R_{\text {int }}\right)$ & $10205(0.0468)$ & $6661(0.0479)$ \\
\hline$R_{1}(\mathrm{I}>2 \sigma(\mathrm{I}))^{\mathrm{a}}$ & 0.0633 & 0.0536 \\
\hline$w R_{2}(\mathrm{I}>2 \sigma(\mathrm{I}))^{\mathrm{a}}$ & 0.1585 & 0.1436 \\
\hline$R_{1}\left(\right.$ all data) ${ }^{a}$ & 0.1048 & 0.0880 \\
\hline$w R_{2}$ (all data) ${ }^{a}$ & 0.1822 & 0.1641 \\
\hline GOF & 1.030 & 1.012 \\
\hline
\end{tabular}


Table 3 Crystallographic data for the coordination networks.

\begin{tabular}{|c|c|c|c|c|c|}
\hline & $\begin{array}{l}{\left[\left(\mathrm{C}_{6} \mathrm{U}-4 \mathrm{Py}\right)_{2} \mathrm{Cu}(\mathrm{hfac})_{2}\right]} \\
(1,2-\mathrm{DCE})_{2}\end{array}$ & $\begin{array}{l}{\left[\left(\mathrm{C}_{6} \mathrm{C}-3 \mathrm{Py}\right)_{2}\right.} \\
\left.\left(\mathrm{Cu}(\mathrm{OAC})_{2}\right)_{2}\right]\left(\mathrm{H}_{2} \mathrm{O}\right)_{2}\end{array}$ & {$\left[\left(\mathrm{C}_{6} \mathrm{~A}-3 \mathrm{Py}\right) \mathrm{Cu}(\mathrm{hfac})_{2}\right]\left(\mathrm{H}_{2} \mathrm{O}\right)$} & $\begin{array}{l}{\left[\left(\mathrm{C}_{6} \mathrm{~A}-3 \mathrm{Py}\right)_{2} \mathrm{Cd}\left(\mathrm{NO}_{3}\right)_{2}\right]} \\
(1,2-\mathrm{DCE})_{0.5}(\mathrm{MeOH})\end{array}$ & $\begin{array}{l}{\left[\left(\mathrm{C}_{6} \mathrm{~A}-4 \mathrm{Py}\right)\left(\mathrm{Cd}\left(\mathrm{NO}_{3}\right)_{2}\left(\mathrm{H}_{2} \mathrm{O}\right)\right)\right]} \\
(1,2-\mathrm{DCE})\end{array}$ \\
\hline Formula & $\mathrm{C}_{48} \mathrm{H}_{48} \mathrm{Cl}_{4} \mathrm{CuF}_{12} \mathrm{~N}_{6} \mathrm{O}_{8}$ & $\mathrm{C}_{42} \mathrm{H}_{56} \mathrm{Cu}_{2} \mathrm{~N}_{8} \mathrm{O}_{12}$ & $\mathrm{C}_{28} \mathrm{H}_{24} \mathrm{CuF}_{12} \mathrm{~N}_{6} \mathrm{O}_{5}$ & $\mathrm{C}_{38} \mathrm{H}_{46} \mathrm{CdClN}_{14} \mathrm{O}_{7}$ & $\mathrm{C}_{20} \mathrm{H}_{26} \mathrm{CdCl}_{2} \mathrm{~N}_{8} \mathrm{O}_{7}$ \\
\hline FW & 1270.26 & 992.02 & 816.07 & 958.74 & 673.79 \\
\hline Crystal system & Triclinic & Triclinic & Triclinic & Monoclinic & Triclinic \\
\hline Space group & $P-1$ & $P-1$ & $P-1$ & $P 2 / n$ & $P-1$ \\
\hline$a / \AA$ & $6.3272(2)$ & $8.3684(4)$ & $8.7579(3)$ & $15.2454(9)$ & $10.3987(3)$ \\
\hline$b / \AA$ & $13.2769(5)$ & $11.1355(6)$ & $11.3344(4)$ & $11.9330(11)$ & $10.8657(4)$ \\
\hline$c / \AA$ & $17.4210(6)$ & $12.3497(7)$ & $18.0717(6)$ & $25.571(2)$ & $10.8657(4)$ \\
\hline$\alpha /^{\circ}$ & $100.252(2)$ & $90.561(2)$ & $78.807(2)$ & & $73.878(2)$ \\
\hline$\beta /{ }^{\circ}$ & $96.189(2)$ & $92.993(2)$ & $85.372(2)$ & $91.001(3)$ & $80.4940(10)$ \\
\hline$\gamma /^{\circ}$ & $91.859(2)$ & $92.055(2)$ & $82.349(2)$ & & $62.957(2)$ \\
\hline$V / \AA^{3}$ & $1429.71(9)$ & $1148.44(11)$ & $1741.33(10)$ & $4651.3(6)$ & $1322.73(8)$ \\
\hline$Z$ & 1 & 1 & 2 & 4 & 2 \\
\hline$T / \mathrm{K}$ & $173(2)$ & $173(2)$ & $173(2)$ & $173(2)$ & $173(2)$ \\
\hline$\mu / \mathrm{mm}^{-1}$ & 0.662 & 0.995 & 0.737 & 0.587 & 1.084 \\
\hline Refls. coll. & 45858 & 52487 & 21635 & 98162 & 23768 \\
\hline Ind. refls. $\left(R_{\text {int }}\right)$ & $7580(0.0387)$ & $6261(0.0418)$ & $8360(0.0375)$ & $10065(0.0615)$ & 7185 (0.0417) \\
\hline$R_{1}(\mathrm{I}>2 \sigma(\mathrm{I}))^{\mathrm{a}}$ & 0.0551 & 0.0276 & 0.0766 & 0.0929 & 0.0316 \\
\hline$w R_{2}(\mathrm{I}>2 \sigma(\mathrm{I}))^{\mathrm{a}}$ & 0.1602 & 0.0713 & 0.2299 & 0.2748 & 0.757 \\
\hline$R_{1}$ (all data) $^{\mathrm{a}}$ & 0.0651 & 0.0320 & 0.0948 & 0.1133 & 0.354 \\
\hline$w R_{2}(\text { all data })^{\mathrm{a}}$ & 0.1717 & 0.0738 & 0.2498 & 0.2953 & 0.0783 \\
\hline GOF & 1.033 & 1.041 & 1.039 & 1.013 & 1.048 \\
\hline
\end{tabular}


Graphical abstract A series of ethynylpyridine-appended nucleobases has been designed, synthesized, characterized and employed for the formation of crystalline molecular networks by hydrogen/coordination bonding.

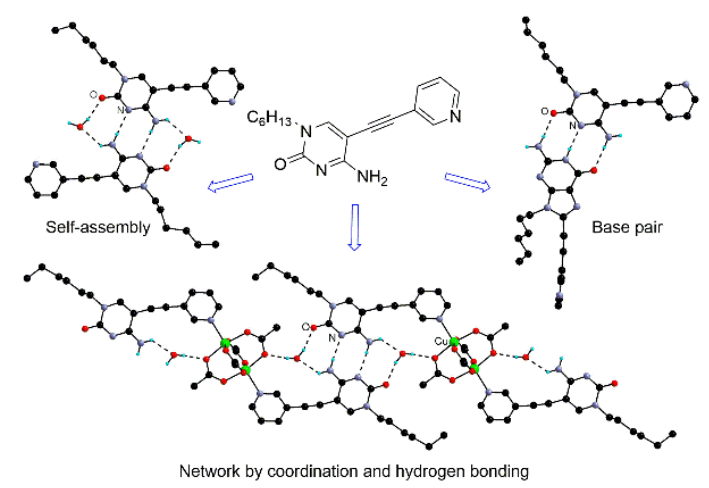

